\title{
Observation and modeling of the evolution of Texas power plant plumes
}

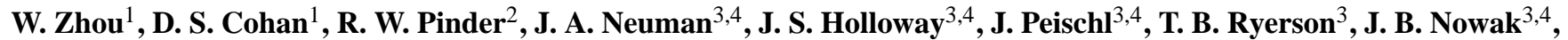 \\ F. Flocke ${ }^{5}$, and W. G. Zheng ${ }^{5}$ \\ ${ }^{1}$ Department of Civil and Environmental Engineering, Rice University, Houston, Texas, USA \\ ${ }^{2}$ Office of Research and Development, US Environmental Protection Agency, North Carolina, USA \\ ${ }^{3}$ Chemical Sciences Division, Earth System Research Laboratory, NOAA, Boulder, Colorado, USA \\ ${ }^{4}$ Cooperative Institute for Research in Environmental Sciences, University of Colorado, Boulder, Colorado, USA \\ ${ }^{5}$ National Center for Atmospheric Research, Boulder, Colorado, USA
}

Correspondence to: W. Zhou (zhouwei@rice.edu)

Received: 24 May 2011 - Published in Atmos. Chem. Phys. Discuss.: 13 July 2011

Revised: 2 December 2011 - Accepted: 31 December 2011 - Published: 9 January 2012

\begin{abstract}
During the second Texas Air Quality Study 2006 (TexAQS II), a full range of pollutants was measured by aircraft in eastern Texas during successive transects of power plant plumes (PPPs). A regional photochemical model is applied to simulate the physical and chemical evolution of the plumes. The observations reveal that $\mathrm{SO}_{2}$ and $\mathrm{NO}_{\mathrm{y}}$ were rapidly removed from PPPs on a cloudy day but not on the cloud-free days, indicating efficient aqueous processing of these compounds in clouds. The model reasonably represents observed $\mathrm{NO}_{\mathrm{x}}$ oxidation and PAN formation in the plumes, but fails to capture the rapid loss of $\mathrm{SO}_{2}\left(0.37 \mathrm{~h}^{-1}\right)$ and $\mathrm{NO}_{\mathrm{y}}$ $\left(0.24 \mathrm{~h}^{-1}\right)$ in some plumes on the cloudy day. Adjustments to the cloud liquid water content (QC) and the default metal concentrations in the cloud module could explain some of the $\mathrm{SO}_{2}$ loss. However, $\mathrm{NO}_{\mathrm{y}}$ in the model was insensitive to QC. These findings highlight cloud processing as a major challenge to atmospheric models. Model-based estimates of ozone production efficiency (OPE) in PPPs are 20-50\% lower than observation-based estimates for the cloudy day.
\end{abstract}

\section{Introduction}

Power plants are the leading point source emitters of $\mathrm{SO}_{2}$ and oxides of nitrogen $\left(\mathrm{NO}_{\mathrm{x}}=\mathrm{NO}+\mathrm{NO}_{2}\right)$. The large amount of $\mathrm{SO}_{2}$ and $\mathrm{NO}_{\mathrm{x}}$ emitted from power plants has been linked to a series of environmental issues, such as acid deposition, photochemical $\mathrm{O}_{3}$ and particulate matter (Srivastava et al., 2004; Ryerson et al., 2001; Brock et al., 2003; Flues et al., 2002). Various regulations and market-based policies have been implemented to reduce these emissions, including the Acid Rain Program (EPA, 2005) and the $\mathrm{NO}_{\mathrm{x}}$ State Implementation Plan Call $\left(\mathrm{NO}_{\mathrm{x}}\right.$ SIP Call) (EPA, 2004) in the United States. Power plants are among the most accurately measured emission sources in the US national emission inventory due to direct smoke stack measurements by Continuous Emission Monitoring Systems (CEMS). Good agreement has been found in comparing power plant emissions reported by CEMS with airborne measurements of power plant plumes (PPPs) (Frost et al., 2006) and with satellite measurements of $\mathrm{NO}_{2}$ (Kim et al., 2006).

The emissions, transport, and chemical evolution of pollutants from power plants have been investigated by multiple observational and modeling methods (Ryerson et al., 1998; Neuman et al., 2004; Godowitch et al., 2008a; Frost et al., 2006; Kim et al., 2006; Sillman, 2000). Airborne measurement of chemical composition and meteorological parameters in PPP transects have been conducted in several field campaigns over North America (Trainer et al., 1995; Ryerson et al., 1998; Springston et al., 2005; Neuman et al., 2009).

$\mathrm{SO}_{2}$ freshly emitted from power plant stacks is quickly diluted and undergoes chemical evolution during plume transport. Previous aircraft measurements in PPPs have revealed that gas-phase $\mathrm{SO}_{2}$ oxidation is the key pathway for the $\mathrm{SO}_{2}$ removal and the particle growth in PPPs in the absence of clouds (Brock et al., 2002, 2003; Springston et al., 2005). $\mathrm{SO}_{2}$ can also readily dissolve in cloud water and then convert to sulfate via aqueous reactions. 
Several previous field studies have investigated the chemical evolution and lifetime of $\mathrm{NO}_{\mathrm{x}}$, ozone production efficiency, and the loss rate of reactive nitrogen in PPPs (Ryerson et al., 1998; Springston et al., 2005; Neuman et al., 2009). Some studies have reported the rapid loss of $\mathrm{NO}_{\mathrm{y}}$ in PPPs which they primarily attributed to $\mathrm{HNO}_{3}$ loss (Neuman et al., 2004; Nunnermacker et al., 2000), but others have not (Ryerson et al., 2003).

Power plants are significant contributors to $\mathrm{NO}_{\mathrm{x}}$ and $\mathrm{SO}_{2}$ emissions and high ozone concentrations in eastern Texas. A NOAA WP-3 aircraft performed successive downwind transects of PPPs in this region during several flights as part of the summer 2006 Second Texas Air Quality Study (TexAQS II) (Parrish et al., 2009). The instruments aboard the WP-3 measured a full range of trace gases, aerosol parameters, and meteorological parameters at high time resolution and spatial resolution. This study utilizes the rich data source to examine whether a 3-D photochemical model with a fine spatial resolution but without subgrid plume treatment can effectively simulate the chemical and physical evolution of PPPs as they disperse and transport downwind. We focus on the evolution of sulfur, reactive nitrogen, and $\mathrm{O}_{3}$ in the plumes.

\section{Airborne measurement}

TexAQS II was a comprehensive observational campaign in eastern Texas from August to October, 2006, which aimed to improve scientific understanding of the sources and atmospheric processes responsible for the formation and distribution of $\mathrm{O}_{3}$ and aerosols in the region (Parrish et al., 2009). PPPs observed during TexAQS II originated from eastern Texas coal-fired power plants with a large range of reported $\mathrm{NO}_{\mathrm{x}}$ and $\mathrm{SO}_{2}$ emission rates (Table 1 and Fig. 1).

The measurements and operational characteristics of the NOAA WP-3 have been summarized elsewhere (Parrish et al., 2009). Instruments aboard the WP-3 measured numerous reactive nitrogen species $\left(\mathrm{NO}, \mathrm{NO}_{2}, \mathrm{HNO}_{3}, \mathrm{NO}_{3}, \mathrm{~N}_{2} \mathrm{O}_{5}\right.$, PAN, peroxy propionyl nitrate, methacrylol peroxy nitrate), isoprene, $\mathrm{CO}_{2}, \mathrm{CO}, \mathrm{SO}_{2}, \mathrm{HCHO}$, major aerosol parameters, UV-VIS actinic flux, relative humidity, and temperature (Tables A1a and A1b of Parrish et al. (2009) and the references therein). The instruments used in measuring major gas-phase species are summarized in Table S2 (in Supplement). The time resolution of most instruments was $1 \mathrm{~s}$, equal to approximately $100 \mathrm{~m}$ spatial resolution at typical WP-3 flying speeds.

Coal-fired power plants are major sources of $\mathrm{SO}_{2}$ and $\mathrm{NO}_{\mathrm{x}}$, so their plumes can be identified by elevated concentrations of $\mathrm{SO}_{2}$ and $\mathrm{NO}_{\mathrm{y}}$ (Ryerson et al., 1998; Ryerson et al., 2003). $\mathrm{SO}_{2}$ enhancement can be a more reliable diagnostic of PPPs than $\mathrm{NO}_{\mathrm{y}}$ since there are numerous sources of $\mathrm{NO}_{\mathrm{x}}$, but coal-fired power plants are dominant sources of $\mathrm{SO}_{2}$ in eastern Texas (Ryerson et al., 2003; Neuman et
Table 1. Major power plants in eastern Texas.

\begin{tabular}{lccc}
\hline Facility & $\begin{array}{c}\mathrm{NO}_{\mathrm{x}} \text { emission } \\
\mathrm{rate}^{\mathrm{a}}\left(\mathrm{th}^{-1}\right)\end{array}$ & $\begin{array}{c}\mathrm{SO}_{2} \text { emission } \\
\mathrm{rate}^{\mathrm{a}}\left(\mathrm{th}^{-1}\right)\end{array}$ & $\begin{array}{c}\text { Stack Height } \\
(\mathrm{m})\end{array}$ \\
\hline Martin Lake & 2.02 & 10.37 & 138 \\
Monticello & 1.34 & 5.49 & 128 \\
Welsh & 0.95 & 2.21 & 172 \\
Pirkey & 0.58 & 0.21 & 160 \\
Big Brown & 0.84 & 13.09 & 122 \\
Parish & 0.33 & 2.74 & 183 \\
Limestone & 0.79 & 0.63 & 137 \\
\hline
\end{tabular}

a emission rate is the hourly averaged CEMS data for Martin Lake, Monticello, and Welsh on 16 September 2006, and for Parish, Big Brown, and Limestone on 25 September 2006 .

al., 2009). Background $\mathrm{SO}_{2}$ levels were consistently below $1 \mathrm{ppb}$, so this level of $\mathrm{SO}_{2}$ is chosen as a threshold value for identifying PPPs.

In rural areas of northeastern Texas, power plants are also leading sources of $\mathrm{CO}$ and anthropogenic $\mathrm{CO}_{2}$ (Nicks et al., 2003), even though CO is not strongly elevated in all PPPs. Airborne measurements in 2000 and 2006 showed that CO and $\mathrm{CO}_{2}$ could be signatures of the Martin Lake, Monticello, and Welsh plumes, the concentration enhancements of which completely overlap $\mathrm{SO}_{2}$ and $\mathrm{NO}_{\mathrm{y}}$ concentration enhancements at transects (Nicks et al., 2003). As the atmospheric lifetime of $\mathrm{CO}_{2}$ is years, it is a conservative species in plumes. CO has a lifetime of one to two months in the atmosphere (Akimoto, 2003), thus serving as another conservative species in PPPs. CO emissions from Martin Lake, Monticello, and Big Brown, which were significantly underestimated in a previous emission inventory (1999), were more accurately estimated in TexAQS II (Peischl et al., 2010).

Of the 18 WP-3 flights during TexAQS II, the 16 September and 25 September flights measured successive crosswind transects of PPPs from multiple power plants and the 19 September flight measured the Parish plume (Fig. 1 and Table S3). The 16 September flight (11:00 to 15:00 local time) observed transects of plumes from the Martin Lake, Pirkey, Monticello, and Welsh power plants at successive downwind distances (Fig. 2a). Since the three plumes transported northward through rural areas devoid of other large anthropogenic $\mathrm{SO}_{2}$ sources, $\mathrm{SO}_{2}$ concentration enhancements clearly denote plume locations (Fig. 2a). Pirkey is located several km north-northeast (downwind) of Martin Lake, so their plumes cannot be distinguished on this flight after the first Martin Lake transect; we refer to the plume as Martin Lake (Ma-1) for simplicity. On 19 September, the WP-3 measured five plume transects of Parish in the Houston-Galveston Brazoria (HGB) metropolitan region. On 25 September (13:00 to 16:00 local time), the WP-3 measured two plume transects of Big Brown and Limestone under northerly flow, and two 


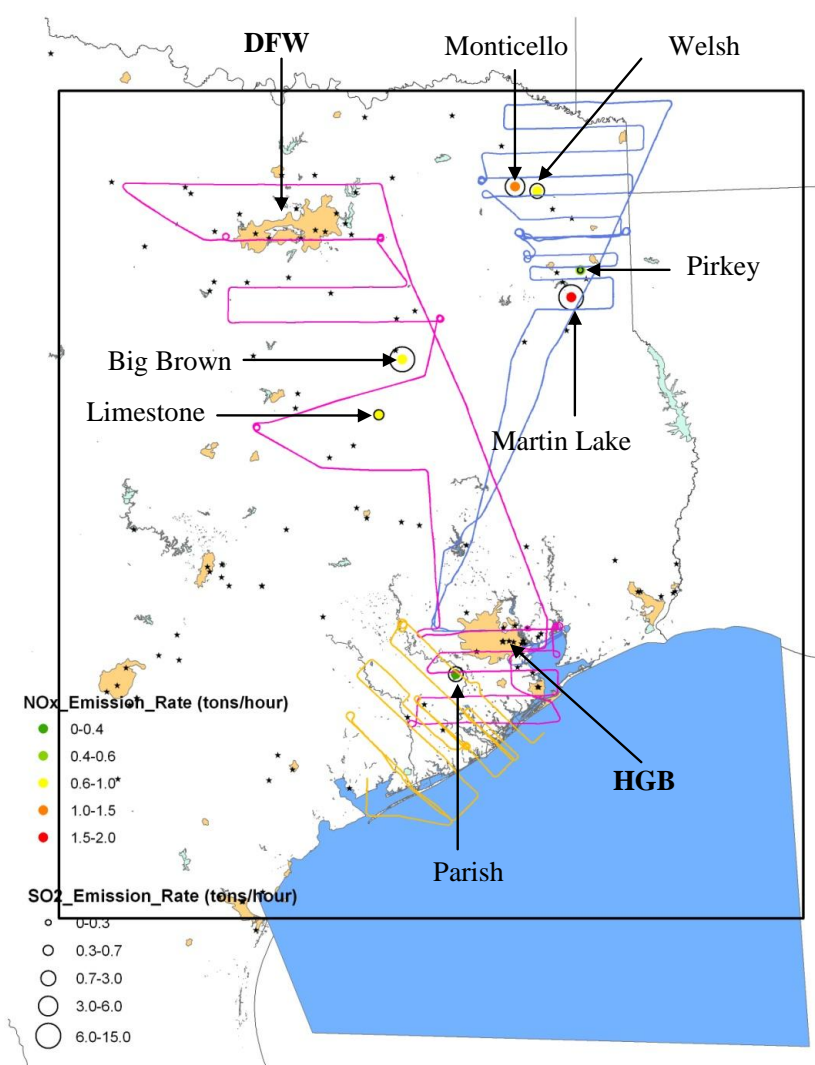

Fig. 1. WP-3 flight tracks (16 September in blue, 19 September in yellow, and 25 September in pink) and power plants in eastern Texas. $\mathrm{NO}_{\mathrm{x}}$ emission rates are shown by colors and $\mathrm{SO}_{2}$ emission rates are indicated by size of circles. Rectangular frame shows the $4 \mathrm{~km}$ modeling domain. Black stars are all other point sources in Texas. The Houston-Galveston-Brazoria (HGB) and Dallas-ForthWorth (DFW) metropolitan areas are also shown.

plume transects of Parish (Fig. S5 and S6 in the Supplement). All transects on the three days occurred at altitudes of 600$700 \mathrm{~m}$, well within the planetary boundary layer height of approximately $1500 \mathrm{~m}$ determined from measured temperature profiles. The exception was five transects (Ma-4 to Ma-8) of the Martin Lake plume at different heights but at the same downwind distance on 16 September.

\section{Model setup and input parameters}

Atmospheric chemistry for the episode was simulated by the Community Multiscale Air Quality (CMAQ) model (Byun and Schere, 2006) version 4.7 (Foley et al., 2010), using the CB05 chemical mechanism (Yarwood et al., 2005). Inline processing was applied to generate the meteorology dependent emissions properties (i.e., biogenic emissions) (Foley et al., 2010). After accounting for plume rise, most of the power plant emissions were modeled to be released between 200 and $600 \mathrm{~m}$ elevation (Fig. S7).
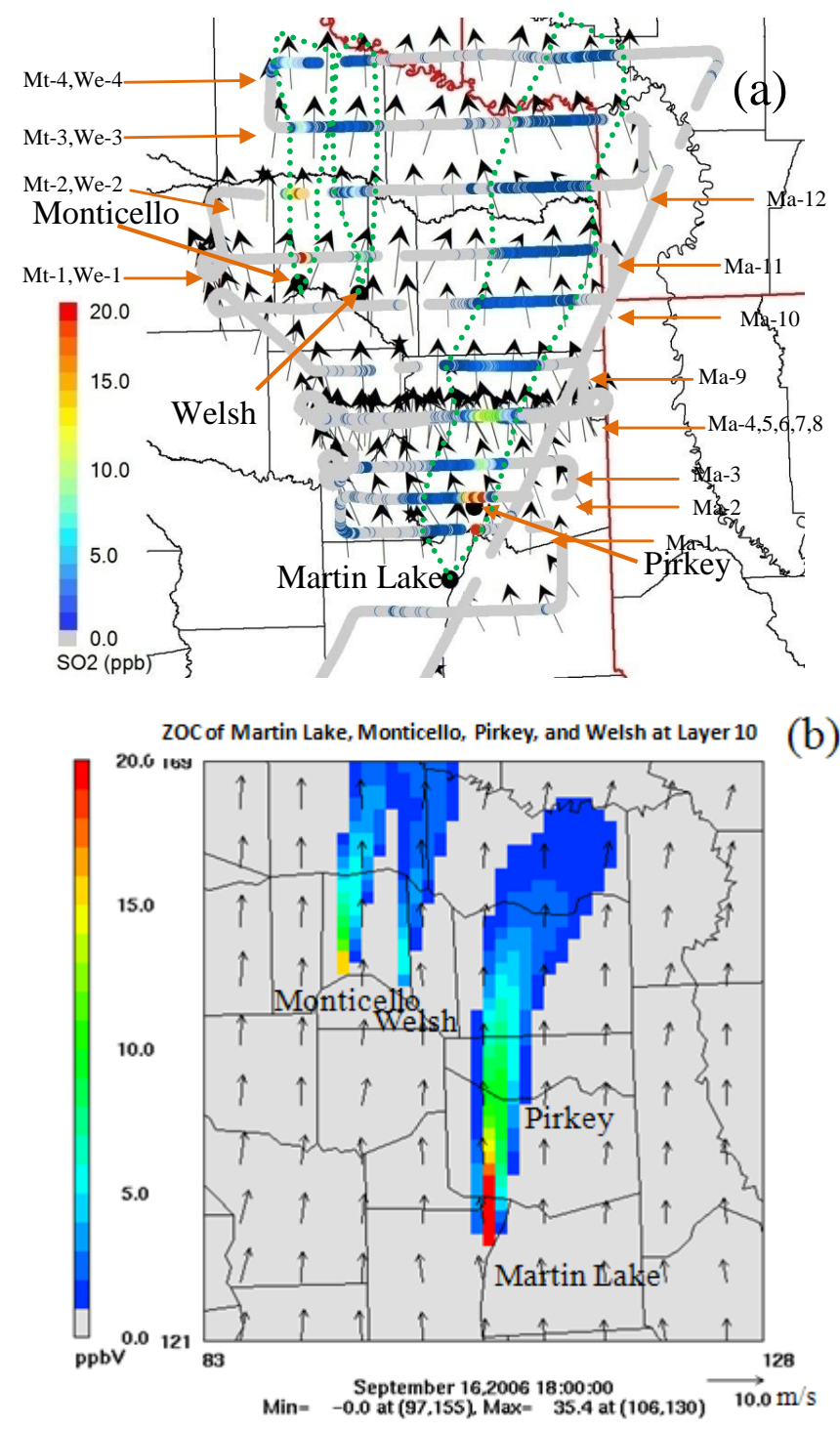

Fig. 2. (a) Observed PPPs of Martin Lake, Monticello, Pirkey, and Welsh on 16 September 2006. The black dots show the locations of the power plants. PPPs are identified by measured $\mathrm{SO}_{2}$ enhancement (color gradient in the figure), as outlined by the green dash lines. Measured wind vectors are presented on the plume transect. The geographical redlines are the state boarder-lines. (b) Simulated PPPs of Martin Lake, Monticello, Pirkey, and Welsh at 18:00 GMT (600 700 m) (local time: 12:00).

The model was configured with 34 vertical layers and three one-way nested domains. The outer two domains cover the continental US $(148 \times 112$ with $36 \mathrm{~km}$ grid resolution) and the eastern US $(279 \times 240$ with $12 \mathrm{~km}$ grid resolution) including all of Texas, respectively. The rectangular frame in Fig. 1 shows the fine domain with $4 \mathrm{~km}$ grid resolution. A full description of the modeling configuration and performance for the $12 \mathrm{~km}$ domain can be found in Appel et al. (2010). The CMAQ modeling for the $4 \mathrm{~km}$ domain 

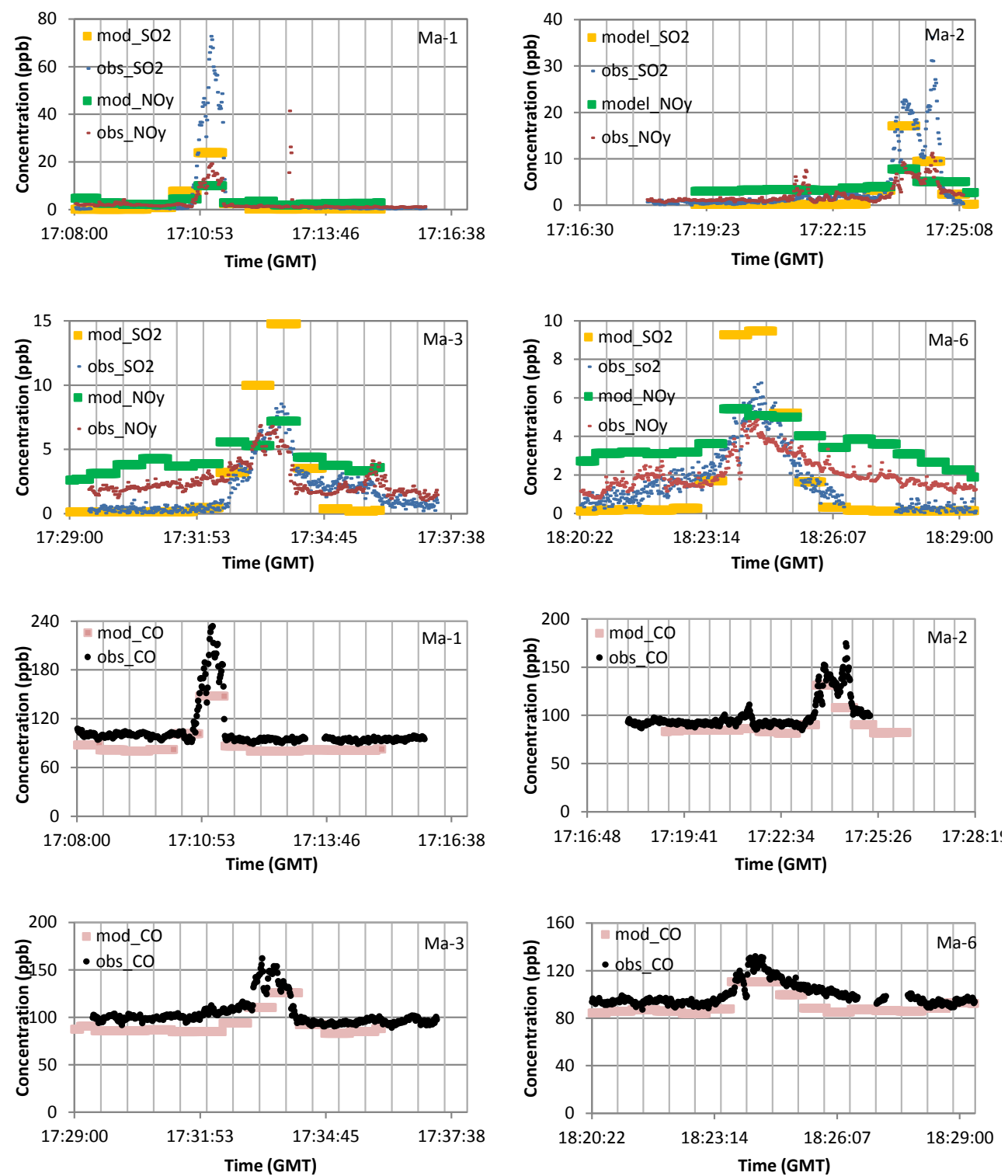

Fig. 3. The comparison of the modeled and observed $\mathrm{SO}_{2}, \mathrm{NO}_{\mathrm{y}}$, and $\mathrm{CO}$ at plume transect of Ma-1, Ma-2, Ma-3 and Ma-6. The modeled $\mathrm{SO}_{2}, \mathrm{NO}_{\mathrm{y}}$, and $\mathrm{CO}$ are labeled as yellow, green, and purple flat lines, respectively. The observed $\mathrm{SO}_{2}, \mathrm{NO}_{\mathrm{y}}$, and $\mathrm{CO}$ are labeled as blue, red and black dots. The Horizontal coordinate is time scale in GMT (local time $=$ GMT $-6 \mathrm{~h}$ ) and vertical coordinate is concentration (ppb). Transect names listed in Table S3 of the manuscript are labled in each subplot. Figures S1-S4 summarize the comparisons for all the plume transects.

was from 1-25 September 2006, which covers the days with WP-3 plume measurements.

Meteorology for the episode was simulated by the FifthGeneration NCAR/Penn State Mesoscale Model (MM5) (Grell et al., 1994) version 3.7.4 for the $36 \mathrm{~km}$ domain. For the inner domains ( $12 \mathrm{~km}$ and $4 \mathrm{~km}$ modeling domains), the Weather Research and Forecasting Model (WRF) version 3.0 (Skamarock et al., 2008) was used because of its lower biases in simulated wind and temperature than MM5. Both models had 34 vertical layers extending from the surface up to $100 \mathrm{hPa}$. WRF was applied with Asymmetric Convec- tive Model 2 PBL model (Pleim, 2007), Pleim-Xiu Land Surface Model (Xiu and Pleim, 2001), Dudhia shortwave radiation scheme (Dudhia, 1989), RRTM longwave radiation scheme (Mlawer et al., 1997), Kain-Fritsch 2 subgrid convective scheme (Kain, 2004), and the Thompson microphysics scheme (Thompson et al., 2004). MM5 used similar physical schemes. The consistency between MM5 and WRF for the modeling domains was tested and verified (Appel et al., 2010). Meteorological fields were converted to CMAQready format by MCIP version 3.4.2 (Otte and Pleim, 2010). 
Emission inputs for the three modeling domains were generated by the Sparse Matrix Operator Kernel Emissions (SMOKE) model (EPA, 2006) based on the National Emission Inventory for 2005. Mobile emissions were projected to 2006 and actual Continuous Emission Monitoring System (CEMS) data were used for point sources. BEIS3.12 (Environmental Protection Agency Biogenic Emissions Inventory System 3.12) (http://www.epa.gov/asmdnerl/biogen. html) was applied to compute the biogenic emissions.

$\mathrm{NO}_{\mathrm{y}}$ species in the CB05 chemical mechanism are NO, $\mathrm{NO}_{2}, \mathrm{NO}_{3}, \mathrm{~N}_{2} \mathrm{O}_{5}, \mathrm{HONO}, \mathrm{HNO}_{3}, \mathrm{PNA}$ (peroxynitric acid), PAN (peroxyacetyl nitrate), PANX (C3 and higher peroxyacyl nitrates), and NTR (organic nitrate). The sum of all these species (with $\mathrm{N}_{2} \mathrm{O}_{5} \cdot 2$ ) is the concentration of $\mathrm{NO}_{\mathrm{y}}$ from the model.

The aqueous processing module in CMAQ (Walcek and Taylor, 1986) processes the absorption of gas-phase species and accumulation-mode aerosols separately. The gas-phase absorption into liquid water content of clouds depends on the thermodynamic equilibrium, whereas accumulation-mode aerosols are assumed to be completely activated to form cloud droplets. The dissociation of compounds into ions, oxidation of $\mathrm{S}(\mathrm{IV})$ to $\mathrm{S}(\mathrm{VI})$ by aqueous $\mathrm{H}_{2} \mathrm{O}_{2}, \mathrm{O}_{3}, \mathrm{Fe}(\mathrm{III})$ and $\mathrm{Mn}$ (II) etc, and wet deposition are also processed in the model. For computational efficiency, CMAQ does not transport cloud-aqueous concentrations separately from gas-phase concentrations between model grids. At the end of the cloud processing module, the cloud concentrations are removed and the mass of each species is passed to either gas-phase or aerosol concentrations.

In this study, the advection schemes used in processing pollutant transport by CMAQ are Piecewise Parabolic Method (PPM) (Colella and Woodward, 1984) and Yamartino-Blackman Cubic Scheme (YAM) (Yamartino, 1993). The Asymmetric Convective Model version 2 (ACM2) (Pleim, 2007) was used to simulate the vertical mixing of pollutants in CMAQ.

To identify and analyze the impact of each power plant, a zero-out simulation is run with the emissions of that facility removed from the base emission inventory. The difference between concentrations in the base simulation and each zeroout simulation represents the zero-out-contribution (ZOC) of that power plant.

\section{Results and discussion}

During airborne measurement on the three days, ground temperature was $24.4-35.5^{\circ} \mathrm{C}$ (average: $29.0^{\circ} \mathrm{C}$ ) and surface wind was $0-7.2 \mathrm{~m} \mathrm{~s}^{-1}$ (average: $3.1 \mathrm{~m} \mathrm{~s}^{-1}$ ) at ground-based monitors in eastern Texas. At $600-700 \mathrm{~m}$ above the ground level (WP-3 typical flying height), the observed ambient temperature was $23.7-30.3^{\circ} \mathrm{C}$ (average: $26.8^{\circ} \mathrm{C}$ ), wind speed was $1.6-12.0 \mathrm{~m} \mathrm{~s}^{-1}$ (average: $6.4 \mathrm{~m} \mathrm{~s}^{-1}$ ) and no precipitation was observed. The height of the planetary boundary layer
(PBL), determined from the vertical profiles of equivalent potential temperature for the three days, was about $1500 \mathrm{~m}$ on 16 September and about $1000 \mathrm{~m}$ in the HGB region on 19 and 25 September.

The CEMS-reported $\mathrm{SO}_{2}$ and $\mathrm{NO}_{\mathrm{x}}$ emissions of big power plants in the eastern US were previously evaluated based on with WP-3 measurements of PPPs in 2004 (Frost et al., 2006). Since the emitted $\mathrm{NO}_{\mathrm{x}}$ in PPPs can quickly be oxidized to $\mathrm{NO}_{\mathrm{z}}\left(\mathrm{NO}_{\mathrm{z}}=\mathrm{NO}_{\mathrm{y}}-\mathrm{NO}_{\mathrm{x}}\right)$, the observed enhancements of $\mathrm{NO}_{y}$ and $\mathrm{SO}_{2}$ serve as the basis for evaluation. The strong correlation between $\mathrm{NO}_{\mathrm{y}}$ and $\mathrm{SO}_{2}$ for all first plume transects $\left(R^{2}=0.68 \sim 0.98\right)$ suggests that the power plants were the dominant sources of these gases there. The three ratios of these plants show strong consistency within the uncertainties of the measurements, although the model slightly under-predicts $\mathrm{SO}_{2} / \mathrm{NO}_{\text {y }}$ ratios (Table 2). Likewise, previous studies have reported strong consistency between $\operatorname{CEMS}\left(\mathrm{SO}_{2} / \mathrm{NO}_{\mathrm{x}}\right)$ and $\mathrm{OBS}\left(\mathrm{SO}_{2} / \mathrm{NO}_{\mathrm{y}}\right)$ (Frost et al., 2006; Ryerson et al., 2003; Ryerson et al., 2001).

\subsection{Evaluation of plume dispersion and transport}

On 16 September, the WP-3 observed mostly southerly winds with average wind speeds of $6.9 \mathrm{~m} \mathrm{~s}^{-1}$. The southerly winds allowed PPPs of Monticello and Welsh to remain distinct in both model and observation (Fig. 2) but caused the Martin Lake and Pirkey plumes to coincide since the two plants are just $18.5 \mathrm{~km}$ apart. Maximal $\mathrm{SO}_{2}$ enhancements for each plume transect were used to identify the plume centers to enable comparative analyses of observations and modeling results. The plumes produced by CMAQ mostly have similar spatial extent to the measured plumes on 16 September (Fig. 2), 19 and 25 September (Figs. S5-S6). The wind speed and direction in the model were more homogeneous than observed winds, resulting in slight differences between modeled and observed locations of the plumes and plume centers (Fig. 2).

The high-resolution aircraft observations were compared with the model outputs extracted from the corresponding grid cells, adjusted to align the modeled and measured plume peak locations as necessary. Since the aircraft was flying consistently at approximately $100 \mathrm{~m} \mathrm{~s}^{-1}$ at each plume transect, each gridline interval in Fig. 3 (40 s) is equal to the spatial distance of $4 \mathrm{~km}$ (one grid cell).

The 16 September flight path proceeded northward in 14 successive crosswind (east-west) transects, the first 12 of which intercepted the Martin Lake (and Pirkey) plumes (Ma1 to Ma-12 in Fig. 2; Ma-4 to Ma-8 are increasing altitudes at the same transect) and the last four of which intercepted the Monticello and Welsh plumes (Fig. 2). The extensive observation of the Martin Lake plume provides a unique opportunity to examine plume evolution from the emission stack until dilution to background levels. Comparisons between modeled and observed $\mathrm{SO}_{2}, \mathrm{NO}_{\mathrm{y}}$, and $\mathrm{CO}$ mixing ratios are shown for each successive plume transect in Figs. S1-S4. 
Table 2. CEMS-reported $\mathrm{E}\left(\mathrm{SO}_{2}\right) / \mathrm{E}\left(\mathrm{NO}_{\mathrm{x}}\right)$ emission molar ratio, the observed $\mathrm{SO}_{2} / \mathrm{NO}_{\mathrm{y}}$ and the modeled $\mathrm{ZOC}_{\mathrm{SO}_{2}} / \mathrm{ZOC}_{\mathrm{NO}_{\mathrm{y}}}$ at the location of the first plume transect.

\begin{tabular}{lcccc}
\hline Plant & $\mathrm{CEMS} \mathrm{SO}_{2} / \mathrm{NO}_{\mathrm{x}}$ & $\mathrm{OBS} \mathrm{SO}_{2} / \mathrm{NO}_{\mathrm{y}}^{\mathrm{a}}$ & $\mathrm{MODEL} \mathrm{ZOC}_{\mathrm{SO}_{2}} / \mathrm{ZOC}_{\mathrm{NO}_{\mathrm{y}}}^{\mathrm{b}}$ & Plume age (hours) \\
\hline Martin Lake & 3.05 & $3.94(0.98)$ & 3.30 & 0.7 \\
Monticello & 2.04 & $3.00(0.86)$ & 1.84 & 0.3 \\
Welsh & 1.10 & $1.20(0.86)$ & 1.08 & 0.4 \\
Big Brown & 8.94 & $10.95(0.97)$ & 9.73 & 1.3 \\
Parish & 5.28 & $6.83(0.68)$ & 5.18 & 0.6 \\
\hline
\end{tabular}

a the values in brackets are the $R^{2}$ of least square fit of $\mathrm{SO}_{2}$ versus $\mathrm{NO}_{\mathrm{y}}$.

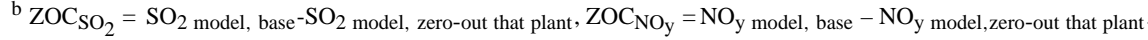

At the first transect of the Martin Lake, Monticello, and Welsh plumes, the model generates lower peak $\mathrm{SO}_{2}$ and $\mathrm{NO}_{\mathrm{y}}$ concentrations and wider plumes than was observed. This likely reflects the inability of the 4- $\mathrm{km}$ resolution model to resolve subgrid-scale plume structure in the initial formation of a plume. No subgrid or Plume-in-Grid (PinG) was used in the modeling.

The model captured the observed extent of $\mathrm{CO}$ at each plume transect, slightly under-estimating the peak values (Fig. 3). The modeled $\mathrm{SO}_{2}(18 \mathrm{ppb})$ at $\mathrm{Ma}-2$ matched the observed peak (23 ppb) closely as subgrid effect weakened and the plume width was larger than one grid cell. As the plume transported to Ma-3, the modeled $\mathrm{SO}_{2}(14 \mathrm{ppb})$ was higher than the observed peak (7 ppb). The modeled $\mathrm{SO}_{2}$ at plume center was consistently higher than the observed while the background $\mathrm{SO}_{2}$ matched observations.

The measured $\mathrm{CO}$ at the plume center declined only from 240 (Ma-1) to $150 \mathrm{ppb}$ (Ma-3). However, $\mathrm{SO}_{2}$ was observed to decline by more than a factor of 10 from Ma-1 to Ma-3, indicating rapid loss.

Ma-4 through Ma-8 observed the Martin Lake plume at the same downwind distance $(53 \mathrm{~km})$ but flew at different altitudes (Ma-4 to Ma-8 of Fig. S1; Table S3). $\mathrm{SO}_{2}$ emission from Martin Lake was modeled to occur mostly at $400 \mathrm{~m}$, accounting for the stack height and plume rise (Fig. S7). At $1800 \mathrm{~m}$ (Ma-4), which was near the top of the PBL, no enhancement of $\mathrm{SO}_{2}, \mathrm{NO}_{\mathrm{y}}$, or $\mathrm{CO}$ was simulated but a weak $\mathrm{SO}_{2}$ plume was observed, implying that the model failed to capture some of the observed upward transport. At lower flight altitudes (between 660 and $300 \mathrm{~m}$, corresponding to Ma-6 to Ma-8 in Fig. S1), the model effectively simulated plume extent. The comparisons between the modeled and observed $\mathrm{SO}_{2}, \mathrm{CO}$ and $\mathrm{NO}_{\mathrm{y}}$ species on 19 and 25 September are shown in Figs. S1 to S4.

\subsection{Correlations between conservative and non-conservative species}

In this section, we explore the correlation between conservative and non-conservative species from the observed plume concentrations. The correlations are presented by the slopes and $R^{2}$ of the least-square-fit between conservative and nonconservative species. At the time scale of PPP transport (a few hours), $\mathrm{CO}$ and $\mathrm{CO}_{2}$ are expected to experience similar dispersion and minimal loss to chemistry or deposition, leading to near constant slopes of $\mathrm{CO}$ to $\mathrm{CO}_{2}$. $\mathrm{CO}$ and $\mathrm{CO}_{2}$ concentrations were strongly correlated within the Martin Lake and Monticello plumes and the slopes of $\mathrm{CO}$ to $\mathrm{CO}_{2}$ held steady as both plumes aged (Fig. 4) (for Ma1 to Ma-3 and Ma-6 to Ma-12, slopes of the least square fit: $\quad 0.58 \sim 0.71 \mathrm{ppb} \mathrm{ppm}^{-1}, R^{2}$ : $0.89 \sim 0.96$; for $\mathrm{Mo}-1$ to Mo-4, slopes of the least square fit: $4.3 \sim 5.3 \mathrm{ppb} \mathrm{ppm}^{-1}$, $R^{2}: 0.77 \sim 0.94$ ), indicating the same extent of dispersion of $\mathrm{CO}$ and $\mathrm{CO}_{2}$. For the Welsh and Big Brown plumes, only the first one or two transects had a strong correlation between $\mathrm{CO}$ and $\mathrm{CO}_{2}$, with the later transects likely affected by nearby $\mathrm{CO}$ or $\mathrm{CO}_{2}$ emissions. Due to the strong interference from HGB urban emissions, no clear correlation between $\mathrm{CO}$ and $\mathrm{CO}_{2}$ could be found in the Parish plume.

Concentrations of $\mathrm{SO}_{2}$ and reactive nitrogen species in PPPs are strongly affected by chemical reactions, heterogeneous conversion, deposition, dispersion, and cloud processing. Dispersion is expected to have the same extent of impact on both conservative (e.g., $\mathrm{CO}_{2}$ and $\mathrm{CO}$ ) and nonconservative species (e.g., $\mathrm{SO}_{2}, \mathrm{NO}_{\mathrm{x}}, \mathrm{HNO}_{3}$, and PAN). Thus, the variations of slopes between non-conservative and conservative species reflect the impact of plume chemistry, deposition and heterogeneous processing on nonconservative species.

Given that $\mathrm{SO}_{2}$ and $\mathrm{CO}_{2}$ were observed to be strongly correlated in all plumes, $\mathrm{CO}_{2}$ could serve well as a signature of PPPs. However, since $\mathrm{CO}_{2}$ is not modeled by $\mathrm{CMAQ}, \mathrm{CO}$ is selected as the conservative species for model-observation comparisons. $\mathrm{CO}$ is a signature emission of some but not all power plants in Texas. In observed PPPs, only in the Martin Lake and Monticello plumes could the strong correlations between the non-conservative species and $\mathrm{CO}$ be found at all transects. In Big Brown and Welsh plumes, $\mathrm{SO}_{2}$ strongly correlates with $\mathrm{CO}$, only in the initial transects. 

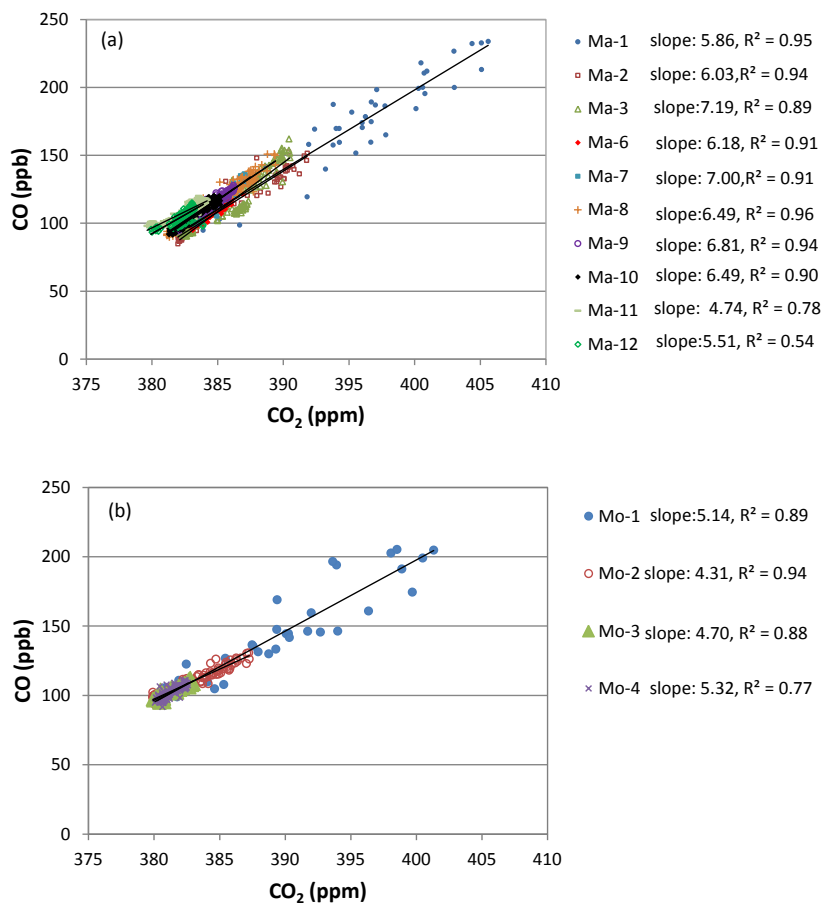

Fig. 4. Scatter plot of $\mathrm{CO}(\mathrm{ppb})$ versus $\mathrm{CO}_{2}$ (ppm) from plume transects (a) Martin Lake (Ma-1 to Ma-12), and (b) Monticello (Mo-1 to Mo-4). The unit of the slopes from the least square fits is $\mathrm{ppb} \mathrm{ppm}^{-1}$.

\subsection{Evaluation of $\mathrm{SO}_{2}$ plume evolution}

MODIS images (http://ladsweb.nascom.nasa.gov/browse images/) and aircraft-observed photolysis rates indicate scattered cloudiness over eastern Texas on 16 September and clear skies on 19 and 25 September (Figs. S8 and S9). Relative humidity reached saturation between $1800 \sim 1000$ m during descents through the Martin Lake plume on 16 September, implying clouds distributed at that altitude and potentially interacting with the plume (Ma-4 and Ma-5 in Fig. S1). The model successfully simulated the MODIS-observed distribution of scattered clouds over northeastern Texas on that day (Figs. S9 and S10), but placed them predominately between 2500 and $4000 \mathrm{~m}$ altitude (Fig. S10), well above the plumes (Figs. S11 and S12). Thus, no significant cloud processing was modeled to occur in the base modeling.

Under the clear skies of 19 September (Fig. S9), the normalized $\mathrm{SO}_{2}$ to $\mathrm{CO}$ ratio from the model and the normalized $\mathrm{SO}_{2}$ to $\mathrm{CO}_{2}$ ratio from the observation matched closely for the Parish plume, showing slow $\mathrm{SO}_{2}$ loss (Fig. 8). At the plume age of $11 \mathrm{~h}$, only $25 \% \mathrm{SO}_{2}$ was removed in both the modeling and the observation. $\mathrm{SO}_{2}$ loss was also slow in the Big Brown and Parish plumes during cloud-free days (Figs. 5 and 8). Thus, the model can capture $\mathrm{SO}_{2}$ evolution when no cloud processing occurs.

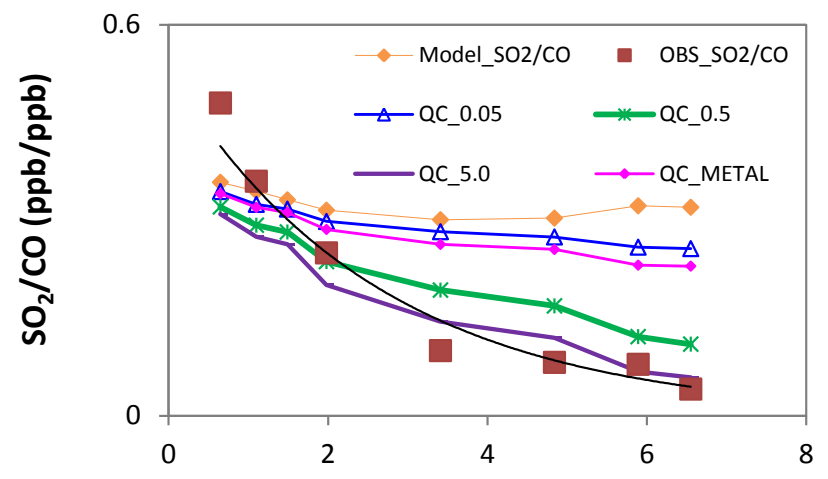

Plume age (hours)

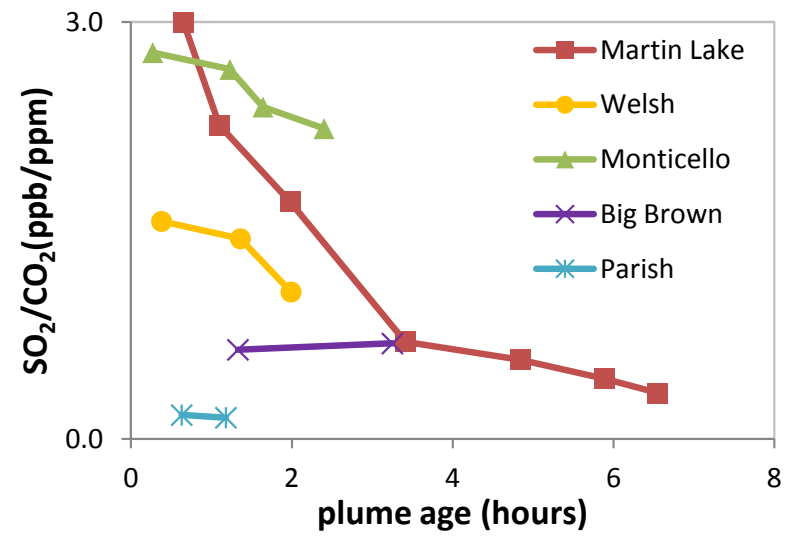

Fig. 5. (a) The observed least square slopes of $\mathrm{SO}_{2}$ to $\mathrm{CO}$ (red square) and modeled $\mathrm{ZOC}_{\mathrm{SO}_{2}} / \mathrm{ZOC}_{\mathrm{CO}}$ (blue diamond for the base case, green dot for the adjusted cloud case) as a function of plume age at each transect of the Martin Lake plume (16 September). The observed $\mathrm{SO}_{2}$ loss rate was $0.38 \mathrm{~h}^{-1}\left(R^{2}=0.94, \mathrm{SO}_{2}\right.$ lifetime: $2.6 \mathrm{~h})$; the modeled $\mathrm{SO}_{2}$ loss rate was $0.016 \mathrm{~h}^{-1}\left(R^{2}=0.36, \mathrm{SO}_{2}\right.$ lifetime: $62.5 \mathrm{~h}$ ). The $\mathrm{SO}_{2}$ to $\mathrm{CO}$ slopes for each perturbation case are also plotted accordingly. (b) The observed least square slopes of $\mathrm{SO}_{2}$ to $\mathrm{CO}_{2}$ (ppb/ppm) for the five plumes; Martin Lake, Welsh, and Monticello plumes were observed on September 16 (cloudy day), Big Brown and Parish plumes were made on 25 September (sunny day).

However, plume observations demonstrate rapid loss of $\mathrm{SO}_{2}$ in the 16 September plumes (Martin Lake, Monticello and Welsh) where scattered clouding was observed (Fig. 5). For the Martin Lake transects, the decreasing trend of $\mathrm{SO}_{2} / \mathrm{CO}$ fits to an exponential function with a first-order loss rate of $0.38 \mathrm{~h}^{-1}$, the inverse of which is a lifetime of $2.6 \mathrm{~h}$ $\left(R^{2}=0.94\right)$ (Fig. 5). $\mathrm{SO}_{2} / \mathrm{CO}$ from the model decreases far slower as plume ages with a loss rate of $0.016 \mathrm{~h}^{-1}$ (lifetime of $62.5 \mathrm{~h}$ ), which suggests the model significantly underestimates $\mathrm{SO}_{2}$ loss for the Martin Lake plume. Similarly, for the Monticello plume, the curve fit of observed $\mathrm{SO}_{2} / \mathrm{CO}$ indicates an $\mathrm{SO}_{2}$ lifetime of $2.7 \mathrm{~h}$ compared to a modeled $\mathrm{SO}_{2}$ lifetime of $17.2 \mathrm{~h}$. Although $\mathrm{SO}_{2}$ and $\mathrm{CO}$ were not strongly 
correlated in observations of the other plumes, diminishing $\mathrm{SO}_{2} / \mathrm{CO}_{2}$ ratios indicate that rapid $\mathrm{SO}_{2}$ loss also occurred in the Welsh plume.

The lifetime of $\mathrm{SO}_{2}$ against gas-phase oxidation by $\mathrm{OH}$ is a few days to one week, and $\mathrm{SO}_{2}$ lifetime against dry deposition approximates one day in the boundary layer. Thus, gas-phase oxidation and dry deposition are insufficient to explain the rapid loss of $\mathrm{SO}_{2}$ in the 16 September plumes.

Could CMAQ have simulated the rapid $\mathrm{SO}_{2}$ loss on 16 September if the meteorological model had placed the clouds at lower altitudes in contact with the PPPs? The cloud module in CMAQ includes two mechanisms for removing pollutants: aqueous chemical reactions and scavenging and wet deposition. $\mathrm{SO}_{2}$ absorption into cloud droplets and subsequent oxidation are explicitly represented. The absorption is governed by thermodynamic equilibrium, followed by oxidation of aqueous $\mathrm{S}(\mathrm{IV})$ to $\mathrm{S}(\mathrm{VI})$ by $\mathrm{H}_{2} \mathrm{O}_{2}, \mathrm{O}_{3}$, metal ions (Fe(III) and $\mathrm{Mn}(\mathrm{II})$ ), and methylhydroperoxide (MHP), and peroxyacetic acid (PAA). Since no precipitation was observed or modeled during the airborne measurements, pollutants were not expected to be scavenged.

Cloud parameters of meteorological inputs are perturbed to diagnose how efficiently pollutants such as $\mathrm{SO}_{2}$ and $\mathrm{NO}_{\mathrm{y}}$ would have been removed from plumes. Specifically, the cloud bottom height in the meteorological field on 16 September is adjusted to 1000 meters so that the plumes interact with clouds during their transport. Liquid water content (QC) is the cloud parameter determining the extent of the pollutant aqueous processing must be larger than $0.01 \mathrm{~g} \mathrm{~kg}^{-1}$ to trigger the cloud aqueous module. In the perturbation cases, we uniformly increase QC to $0.05 \mathrm{~g} \mathrm{~kg}^{-1}$ $\left(\approx 0.05 \mathrm{~g} \mathrm{~m}^{-3}\right.$, equivalent to fog), $0.5 \mathrm{~g} \mathrm{~kg}^{-1}\left(\approx 0.5 \mathrm{~g} \mathrm{~m}^{-3}\right.$, equivalent to stratocumulus clouds), and $5 \mathrm{~g} \mathrm{~kg}^{-1}\left(\approx 5 \mathrm{~g} \mathrm{~m}^{-3}\right.$, equivalent to cumulonimbus clouds).

In the base modeling for the Martin Lake plume, only $11 \%$ $\mathrm{SO}_{2}$ is removed in the model (the normalized $\mathrm{SO}_{2} / \mathrm{CO}$ decreased to 0.89 from Ma-1 to Ma-12). In the QC_0.05 case, $25 \%$ of $\mathrm{SO}_{2}$ is removed during that span, far short of the observed $92 \% \mathrm{SO}_{2}$ removal (Fig. 5). The cloudier scenarios yield $66 \%\left(\mathrm{QC}=0.5 \mathrm{~g} \mathrm{~kg}^{-1}\right)$ and $81 \%\left(\mathrm{QC}=5.0 \mathrm{~g} \mathrm{~kg}^{-1}\right)$ $\mathrm{SO}_{2}$ removal, still below the observed rate.

Five S(IV) oxidation reactions are explicitly implemented in the cloud aqueous module, i.e. $\mathrm{H}_{2} \mathrm{O}_{2}, \mathrm{O}_{3}$, metal (Fe(III) and $\mathrm{Mn}(\mathrm{II}))$, MHP, and PAA oxidations. In QC_0.05, S(IV) oxidation is dominated by $\mathrm{H}_{2} \mathrm{O}_{2}$ oxidation, with $96.2 \%$ of S(IV) oxidation occurring by $\mathrm{H}_{2} \mathrm{O}_{2}$ in the Martin Lake plume. Only about $1.7 \%$ of $\mathrm{S}(\mathrm{IV})$ oxidation was by the metal ions.

In the default CMAQ cloud module, Fe(III) and Mn(II) are uniformly set to 0.01 and $0.005 \mu \mathrm{g} \mathrm{m}{ }^{3}$, representative of the background atmosphere. However, power plants are major emission sources of particulate metals (Alexander et al., 2009), and may have much higher levels of Fe(III) and $\mathrm{Mn}(\mathrm{II})$, thus potentially enhancing the aqueous oxidation of sulfur in PPPs. In another perturbation case, both Fe(III) and
$\mathrm{Mn}$ (II) concentrations are increased by a factor of 10 in the QC_0.05 case (called QC_METAL hereafter). The increase of $\mathrm{Fe}$ (III) and $\mathrm{Mn}$ (II) is within the range of metal ion concentrations measured in fogs and cloud water (Raja et al., 2005; Parazols et al., 2006). $\mathrm{SO}_{2}$ removal in QC_METAL was more rapid than that of QC_0.05 (Fig. 5). At the last plume transect, $\mathrm{SO}_{2}$ decreased by $33 \%$, compared to the $25 \% \mathrm{SO}_{2}$ removal in QC_0.05, suggesting the increased metals in plume lead to more rapid $\mathrm{SO}_{2}$ oxidation. Thus, some combination of enhancements in cloud liquid water content and metals concentrations may help explain the observed rapid $\mathrm{SO}_{2}$ loss rates in the cloudy day plumes.

Few studies have observed rapid $\mathrm{SO}_{2}$ loss in anthropogenic plumes, though similar rates of $\mathrm{SO}_{2}$ loss have been found in volcanic plumes (Oppenheimer et al., 2010; Rodríguez et al., 2008). These studies proposed that cloud aqueous processing is the mechanism for the rapid $\mathrm{SO}_{2}$ removal. The comprehensive airborne measurement of plume concentrations and meteorological parameters supported by satellite images in this study confirms that the cloud processing caused the rapid $\mathrm{SO}_{2}$ loss. $\mathrm{SO}_{2}$ uptake by cloud droplet and subsequent aqueous oxidation are a major challenge to models. Earlier studies have also found that models can underestimate $\mathrm{SO}_{2}$ loss rates in clouds (Crutzen and Lawrence, 2000; Kreidenweis et al., 1997).

\subsection{Evaluation of plume chemistry of reactive nitrogen}

In PPPs, $\mathrm{HNO}_{3}, \mathrm{NO}_{3}, \mathrm{~N}_{2} \mathrm{O}_{5}, \mathrm{PAN}$, and other organic nitrates are formed via $\mathrm{NO}_{\mathrm{x}}$ chemical reactions. Freshly emitted $\mathrm{NO}_{\mathrm{x}}$ titrates $\mathrm{O}_{3}$ and consumes $\mathrm{OH}$, resulting in slow formation of $\mathrm{HNO}_{3}$ and no formation of PAN in the initial plume (Karamchandani et al., 1998). As a plume dilutes, $\mathrm{OH}$ levels recover and $\mathrm{HNO}_{3}$ and other products form from $\mathrm{NO}_{\mathrm{x}}$ oxidation. Previous daytime observations of PPPs concluded that $\mathrm{HNO}_{3}$ and PAN were the major (more than $90 \%$ ) products of $\mathrm{NO}_{\mathrm{x}}$ oxidation in PPPs (Neuman et al., 2006; Neuman et al., 2004; Ryerson et al., 2003; Ryerson et al., 2001). The observational data in this study also show that $\mathrm{HNO}_{3}$ and PAN were the only two major oxidation products in PPPs, with $\mathrm{NO}_{3}$ and $\mathrm{N}_{2} \mathrm{O}_{5}$ and other organic nitrates at least one order of magnitude lower in plume transects.

The measured and modeled $\mathrm{NO}_{\mathrm{x}}, \mathrm{HNO}_{3}$, and PAN are shown for comparison in Figs. S2 and S3. $\mathrm{NO}_{\mathrm{x}}$ was higher than $\mathrm{HNO}_{3}$ until the plume transported $2.0 \mathrm{~h}$ at Ma-7 and Ma-8. The model generally captured the observed evolution of reactive nitrogen species $\mathrm{NO}_{\mathrm{x}}, \mathrm{HNO}_{3}$, and PAN in the plume, simulating the transition from $\mathrm{NO}_{\mathrm{x}}$ to $\mathrm{HNO}_{3}$ dominance and approximately matching the observed PAN levels. However, the simulated $\mathrm{HNO}_{3}$ concentrations were higher than observed, implying over-prediction of $\mathrm{HNO}_{3}$ formation or under-prediction of $\mathrm{HNO}_{3}$ loss.

The oxidation of $\mathrm{NO}_{\mathrm{x}}$ by radicals approximates as a firstorder reaction if radical concentrations are assumed to be constant in the plume. The observed $\mathrm{NO}_{\mathrm{x}} / \mathrm{CO}$ fits to an 

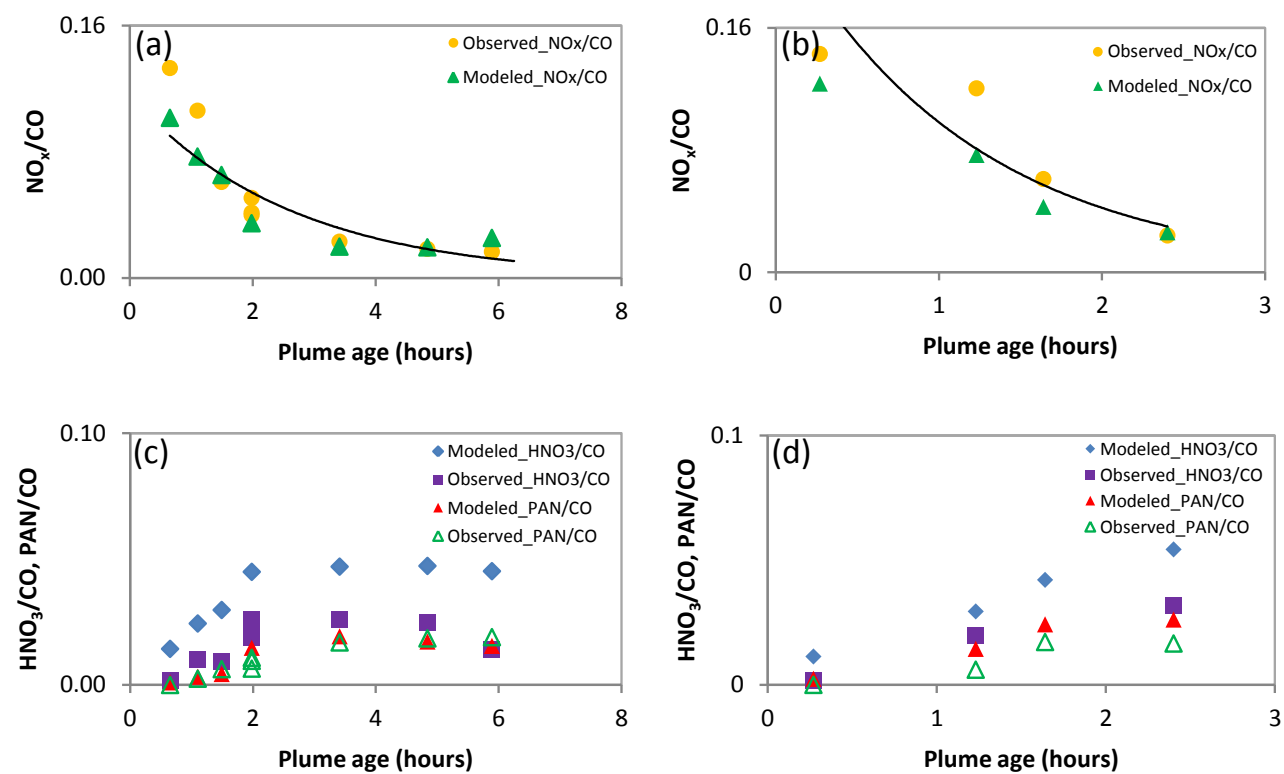

Fig. 6. Observed (yellow circle) and modeled (green triangle) $\mathrm{NO}_{\mathrm{x}} / \mathrm{CO}$ (a) for the Martin Lake plume, (b) for the Monticello plume. The observed $\mathrm{NO}_{\mathrm{x}}$ oxidation rate was $0.38 \mathrm{~h}^{-1}\left(R^{2}=0.85\right)$ for the Martin Lake plume and $0.84 \mathrm{~h}^{-1}\left(R^{2}=0.86\right)$ for the Monticello plume. Observed and modeled PAN/CO and $\mathrm{HNO}_{3} / \mathrm{CO}$, (c) for the Martin Lake plume, (d) for the Monticello plume.

exponential decay function (for Martin Lake, $R^{2}=0.85$; for Monticello, $R^{2}=0.86$; Fig. 6), corresponding to $\mathrm{NO}_{\mathrm{x}}$ lifetimes of 2.6 and $1.2 \mathrm{~h}$ for the Martin Lake and Monticello plumes, respectively. The $\mathrm{NO}_{\mathrm{x}}$ lifetimes computed here are consistent with the $\mathrm{NO}_{\mathrm{x}}$ lifetimes $(1.0 \sim 1.6 \mathrm{~h})$ estimated for both plants in TexAQS 2000 (Neuman et al., 2004). The declining trends of $\mathrm{NO}_{\mathrm{x}} / \mathrm{CO}$ from the model and the observation closely match in the Martin Lake and Monticello plumes, with discrepancies only in the initial transects due to the inability of the model to resolve subgrid-scale plume structure (Fig. 6).

The ratios of $\mathrm{HNO}_{3} / \mathrm{CO}$ and $\mathrm{PAN} / \mathrm{CO}$ are compared between the model and observations to explore chemical evolution in the Martin Lake and Monticello plumes. We find that the model captures the PAN formation very well, closely matching observed trends as the plumes age (Figs. 6 and S2). The modeled $\mathrm{HNO}_{3} / \mathrm{CO}$, however, was $0.7 \sim 6.6$ times larger than observed. Given the good agreement between the modeled and observed $\mathrm{NO}_{\mathrm{x}}$ oxidation and PAN formation, the $\mathrm{HNO}_{3}$ gap between the model and the observation on the cloudy day implies that $\mathrm{HNO}_{3}$, while formed during plume transport, was rapidly removed from the atmosphere, which is not captured by the model.

Unexpectedly rapid loss of $\mathrm{NO}_{\mathrm{y}}$ has also been reported by some measurement studies of biomass burning (Takegawa et al., 2003) and PPPs (Neuman et al., 2004), but not in others (Ryerson et al., 2003). When $\mathrm{NO}_{\mathrm{x}}$ is oxidized to other reactive nitrogen species, the reactive nitrogen may be removed from the atmosphere via rain scavenging, dry deposition, heterogeneous conversion to aerosol, and cloud pro- cessing, resulting in the loss of $\mathrm{NO}_{\mathrm{y}}$. Assuming a first-order decline of $\mathrm{NO}_{\mathrm{y}} / \mathrm{CO}$ (Fig. 7), the observed $\mathrm{NO}_{\mathrm{y}}$ loss rate was $0.15 \mathrm{~h}^{-1}$ for the Martin Lake plume whereas the modeled $\mathrm{NO}_{\mathrm{y}}$ loss rate was lower by a factor of $6\left(0.026 \mathrm{~h}^{-1}\right)$. For the Monticello plume, the observed $\mathrm{NO}_{\mathrm{y}}$ loss rate $\left(0.24 \mathrm{~h}^{-1}\right)$ was 2.3 times the modeled. The observed $\mathrm{NO}_{\mathrm{y}} / \mathrm{CO}_{2}$ in Martin Lake, Monticello, and Welsh plumes had a similar extent of $\mathrm{NO}_{\mathrm{y}}$ loss, especially during the early plume age $(\leq 2 \mathrm{~h})$ when $\mathrm{NO}_{\mathrm{y}} / \mathrm{CO}$ declined by $40 \sim 50 \%$ (Fig. 7).

On 19 September, a cloud-free day, the model effectively simulates the observed slow removal of $\mathrm{NO}_{\mathrm{y}}$ (Fig. 8). $\mathrm{NO}_{\mathrm{y}}$ loss on the cloudy day likely reflects deposition of highly soluble $\mathrm{HNO}_{3}$, since the other main $\mathrm{NO}_{\mathrm{y}}$ constituents $\left(\mathrm{NO}_{\mathrm{x}}\right.$ and PAN) have low water solubility, cannot directly convert to aerosol, and have negligible dry deposition in plume. $\mathrm{NO}_{\mathrm{x}}$ oxidation and thermal decomposition of PAN do not shift the gas-phase $\mathrm{NO}_{\mathrm{y}}$ budget since their products are also gas-phase $\mathrm{NO}_{\mathrm{y}}$ constituents. The measured $\mathrm{NO}_{3}^{-}$was minor in the inorganic aerosol composition, indicating that the loss of $\mathrm{HNO}_{3}$ to aerosol- $\mathrm{NO}_{3}^{-}$was negligible under the high ambient temperatures (the measured average temperature was $28.9^{\circ} \mathrm{C}$ ) and the lack of ammonia enhancement beyond levels needed to neutralize the sulfate in the PPPs (Nowak et al., 2010). Given that no wet precipitation was reported on the flight days, no rain scavenging is expected to have occurred. $\mathrm{HNO}_{3}$ may have rapidly dissolved in cloud droplets if the plume interacted with a cloud, as is possible under the 16 September scattered cloudiness conditions discussed earlier.

In contrast to the $\mathrm{SO}_{2}$ results, the cloud perturbation scenarios did not significantly impact modeled concentrations 

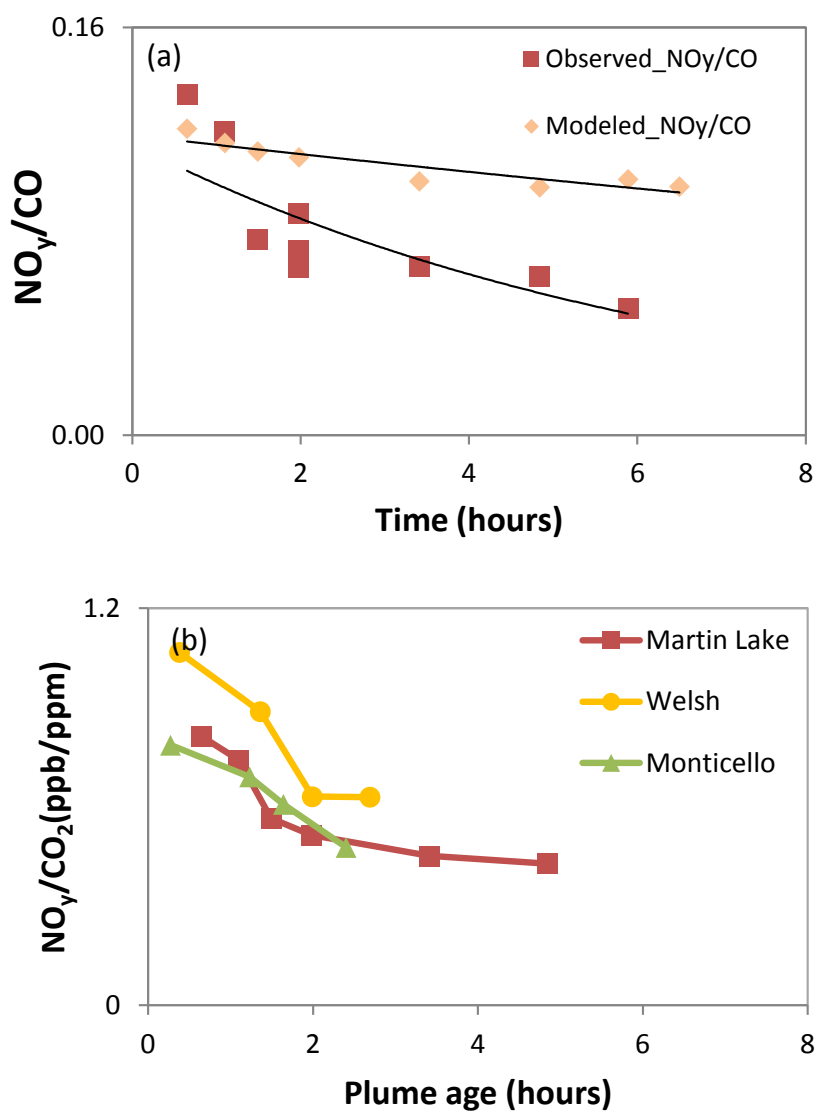

Fig. 7. (a) The observed least square slopes of $\mathrm{NO}_{\mathrm{y}}$ to $\mathrm{CO}$ (red square) and modeled $\mathrm{ZOC}_{\mathrm{NO}_{\mathrm{y}}} / \mathrm{ZOC}_{\mathrm{CO}}$ (orange diamond for the base case, green dot for the adjusted cloud case) as a function of plume age at each transect of the Martin Lake plume; the observed $\mathrm{NO}_{\mathrm{y}}$ loss rate was $0.145 \mathrm{~h}^{-1}\left(R^{2}=0.69\right)$ and the modeled $\mathrm{NO}_{\mathrm{y}}$ loss rate was $0.026 \mathrm{~h}^{-1}\left(R^{2}=0.48\right)$. (b) The observed least square slopes of $\mathrm{NO}_{\mathrm{y}}$ to $\mathrm{CO}_{2}\left(\mathrm{ppb} \mathrm{ppm}^{-1}\right)$ for the Martin Lake, Monticello, and Welsh. $\mathrm{NO}_{\mathrm{y}}$ in the least-square fits was directly measured and not the sum of measured reactive nitrogen species.

of $\mathrm{NO}_{\mathrm{y}}$ species. Among $\mathrm{NO}_{\mathrm{y}}$ species, $\mathrm{HNO}_{3}$ is the only one to be processed by the cloud module. Even raising QC to $5.0 \mathrm{~g} \mathrm{~kg}^{-1}$, there is no scavenging removal of $\mathrm{HNO}_{3}$ since no wet deposition happens in the absence of precipitation. At the end of the cloud module, CMAQ returns the aqueous concentration of $\mathrm{HNO}_{3}$ in cloud to either gas-phase or aerosol species, keeping the ratio of $\mathrm{HNO}_{3}$ to total $\mathrm{NO}_{\mathrm{y}}$ constant. This makes $\mathrm{HNO}_{3}$ concentrations insensitive to QC in CMAQ.

\subsection{Evaluation of $\mathrm{O}_{3}$ simulation in PPPs}

Various numerical models have been applied to simulate the $\mathrm{O}_{3}$ chemistry of PPPs (Sillman, 2000; Springston et al., 2005; Frost et al., 2006; Zaveri et al., 2010). The simulation of the chemistry and transport of PPPs by 3-D models are widely used for assessing the effectiveness of emission con-
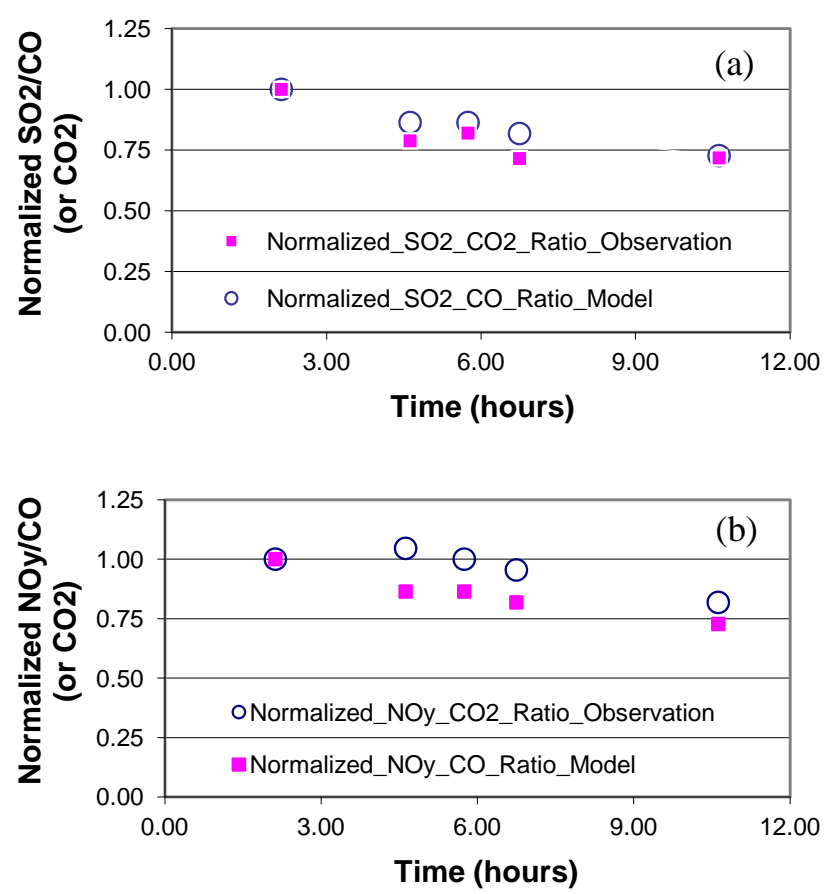

Fig. 8. The least-square-fit slopes of $\mathrm{SO}_{2}$ to $\mathrm{CO}_{2}$ (from the observation) and $\mathrm{SO}_{2}$ to $\mathrm{CO}$ (from the model) (a), and the least-square-fit slopes of $\mathrm{NO}_{\mathrm{y}}$ to $\mathrm{CO}_{2}$ (from the observation) and $\mathrm{NO}_{\mathrm{y}}$ to $\mathrm{CO}$ (from the observation) (b). All slopes are normalized to the slope at the first transect.

trols of power plant pollutants. However, the performance of these models has most often been evaluated with ground concentrations (Mauzerall et al., 2005; Vijayaraghavan et al., 2009; Godowitch et al., 2008a; Godowitch et al., 2008b).

The model overestimated background $\mathrm{O}_{3}$ by $8 \sim 15 \mathrm{ppb}$ during the flights (Table S4). Sensitivity modeling shows that boundary conditions were the biggest contributor to background $\mathrm{O}_{3}$ levels. Thus, we focus on the differences $\left(\Delta \mathrm{O}_{3}\right)$ between plume and background $\mathrm{O}_{3}$ mixing ratios to assess model performance for $\mathrm{O}_{3}$ formation from power plant plumes (Table S4).

The model accurately simulates that the Monticello and Welsh plumes shift from being depleted to being enriched in $\mathrm{O}_{3}$ between transect 1 and 2, and predicts the transition to occur one transect sooner than observed for Martin Lake. All of these plumes traversed rural regions of northeastern Texas where biogenic isoprene is abundant. However, the model underestimates the amount of $\mathrm{O}_{3}$ enrichment downwind by $20-70 \%$ (Ma-9 to Ma-12, Mo-2 to Mo-4, We-2 to We-4). The model also underestimates titration in the initial transects, reflecting the more rapid dilution of $\mathrm{NO}_{\mathrm{x}}$ in the model.

Ozone Production Efficiency (OPE) quantifies the number of $\mathrm{O}_{3}$ molecules formed per molecule of $\mathrm{NO}_{\mathrm{x}}$ irreversibly oxidized to $\mathrm{NO}_{\mathrm{z}}$ species (Liu et al., 1987). Here, we determine OPE in the model from the ratio $\mathrm{ZOC}_{\mathrm{O}_{3}}$ to $\mathrm{ZOC}_{\mathrm{NO}_{\mathrm{Z}}}$, 


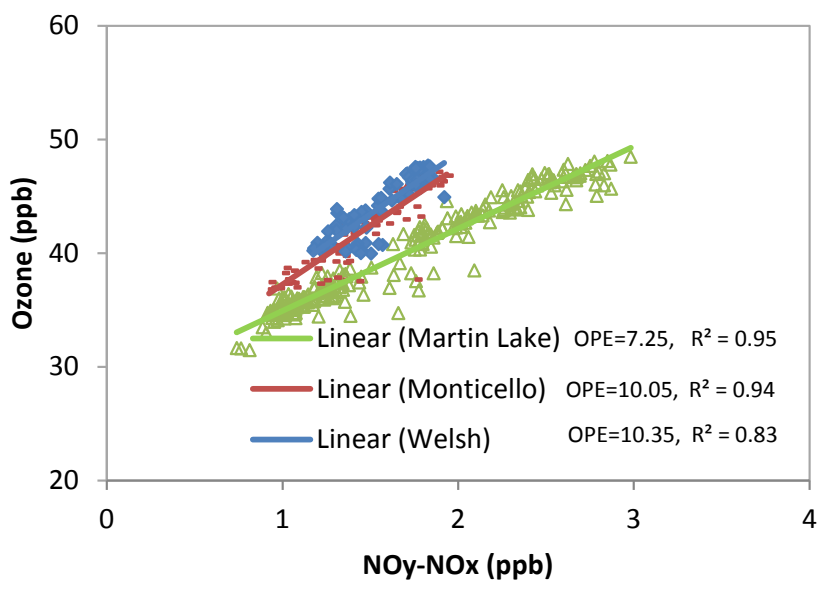

Fig. 9. $\mathrm{O}_{3}$ versus $\mathrm{NO}_{\mathrm{y}}-\mathrm{NO}_{\mathrm{x}}$ from the transects of Martin Lake (Ma-6, plume age of $2.0 \mathrm{~h}$ ), Monticello (Mo-4, plume age of $2.4 \mathrm{~h}$ ), and Welsh (We-4, plume age of $2.7 \mathrm{~h})$. The slopes from the least square fits indicate the observation-based estimates of OPE from each plume transect.

and in the measurements from the least square slope of $\mathrm{O}_{3}$ versus $\mathrm{NO}_{\mathrm{y}}-\mathrm{NO}_{\mathrm{x}}\left(\mathrm{NO}_{\mathrm{z}}\right)$ (Trainer et al., 1993; Kleinman et al., 2002; Griffin et al., 2004; Ryerson et al., 2003).

Observations of Martin Lake, Monticello, and Welsh transects show OPE steadily increasing, while $\mathrm{O}_{3}$ production evolves from depletion to net formation, consistent with OPE trends from PPPs in the southeast US (Ryerson et al., 2001) and in Texas in 2000 (Springston et al., 2005; Ryerson et al., 2003). OPEs from transects of these plumes (Ma-6, Mo4, and We-4) at similar plume ages are compared in Fig. 9. OPEs for Monticello and Welsh were remarkably similar (Fig. 9), reflecting approximately equal $\mathrm{O}_{3}$ formation potentials of these facilities with similar $\mathrm{NO}_{\mathrm{x}}$ emission rates (Table 1). Martin Lake emitted about two times as much $\mathrm{NO}_{\mathrm{x}}$ as Monticello and Welsh, and thus exhibited a smaller OPE. Comparing younger transects, OPE in the Big Brown plume (Bi-1) was 1.7 at a plume age of $1.3 \mathrm{~h}$, lower than the similarplume-age OPE of Martin Lake (2.6, Ma-3) and Welsh (4.6, We-2), but close to the OPE of Monticello (1.4, Mo-2). OPE could not be quantified in the subsequent Big Brown transect due to lack of correlation between $\mathrm{O}_{3}$ and $\mathrm{NO}_{\mathrm{z}}$. The Parish plume exhibited an OPE of 4.4 at a plume age of just $0.6 \mathrm{~h}$, suggesting rapid $\mathrm{O}_{3}$ formation under the influence of Houston region anthropogenic VOCs.

The model replicated the observed temporal trends in OPE but simulated maximum OPEs about a factor of 2 lower than observed (Table S4). Since the calculation of OPE implicitly assumes that $\mathrm{NO}_{\mathrm{y}}$ is conservative in plumes, the rapid loss of $\mathrm{NO}_{\mathrm{y}}$ observed but not modeled on the cloudy day (Table S4) may undermine the accuracy of the observation-based OPE.

It should also be noted that the model tended to underpredict measured isoprene concentrations. Observed isoprene concentrations averaged over all transects are higher than the modeled average by $51.3 \%$. We perturb domainwide isoprene emission rates by this factor in the model to investigate how much impact the isoprene discrepancy has on the $\mathrm{O}_{3}$ formation in plumes. After perturbation, the simulated $\mathrm{ZOC}_{O 3}$ has a maximum increase of $3 \mathrm{ppb}(\mathrm{Ma}-2)$. The maximum $\mathrm{O}_{3}$ increase for Monticello and Welsh is 1.5 and $2 \mathrm{ppb}$, respectively. OPEs of Martin Lake, Monticello, and Welsh plumes would increase to 7.0, 7.8, and 5.9, respectively, closing roughly half of the gap between modeled and observed OPEs. For Big Brown, the OPE would increase by a factor of 1.4, and for Parish, the OPE would increase to 6 (Pa-2), exceeding the observed OPE (4.4).

\section{Summary and conclusions}

A regional 3-D photochemical model was applied with finegrid resolution to simulate PPPs during three days of airborne measurement by NOAA's WP-3 aircraft in TexAQS II. In this modeling study, the modeled and airborne observed concentrations are compared in detail at each plume transect. Under steady wind meteorological conditions, the fine-scale $(4 \mathrm{~km})$ CMAQ accurately simulated the transport and dispersion of PPPs despite lacking a plume-in-grid module.

$\mathrm{SO}_{2}$ and $\mathrm{NO}_{\mathrm{x}}$ show strong consistencies among the CEMS-reported emission data. In the Martin Lake and Monticello plumes, $\mathrm{CO}$ was strongly correlated with $\mathrm{SO}_{2}$ and $\mathrm{NO}_{\mathrm{y}}$ and could serve as a conservative tracer species to track plume evolution; $\mathrm{CO}_{2}$ was strongly correlated with $\mathrm{SO}_{2}$ and $\mathrm{NO}_{\mathrm{y}}$ in all plumes but was not modeled by CMAQ. The trend in the least square slopes of pollutants relative to $\mathrm{CO}\left(\mathrm{CO}_{2}\right)$ was used to assess species lifetime.

On clear-sky days (19 and 25 September), $\mathrm{SO}_{2}$ and $\mathrm{NO}_{\mathrm{y}}$ experienced slow evolution (loss) in the Parish and Big Brown plumes. Both the model and the observation were closely correlated in the ratios of $\mathrm{SO}_{2}$ and $\mathrm{NO}_{\mathrm{y}}$ to conservative species, suggesting the model well captured $\mathrm{SO}_{2}$ and $\mathrm{NO}_{\mathrm{y}}$ evolution in the plumes.

$\mathrm{SO}_{2}$ was observed to be rapidly lost in the Martin Lake, Monticello, and Welsh plumes under scattered cloudiness on 16 September. The observation-based $\mathrm{SO}_{2}$ lifetime was 2.6 and $2.7 \mathrm{~h}$ for the Martin Lake and Monticello plumes, respectively. The detailed examination of the photolysis rate and relative humidity data suggested cloud-processing of PPPs caused the rapid $\mathrm{SO}_{2}$ loss on 16 September. The original simulation did not show the apparent $\mathrm{SO}_{2}$ loss since PPPs resided below clouds in the model. Perturbing the cloud bottom heights to interact with the PPPs yielded modest rates of $\mathrm{SO}_{2}$ removal via aqueous processing in the CMAQ cloud module. $\mathrm{SO}_{2}$ removal in the model was still slower than the observed rapid loss, even after increasing cloud liquid water content and metals concentrations in cloud droplets to enhance $\mathrm{SO}_{2}$ oxidation.

The simulation closely matched the observed $\mathrm{NO}_{\mathrm{x}}$ oxidation rates. The observed $\mathrm{NO}_{\mathrm{x}}$ lifetime for Martin Lake 
and Monticello plumes was $2.6 \mathrm{~h}$ and $1.2 \mathrm{~h}$, respectively. The modeled PAN formation reflected the observed trend of PAN formation, while the modeled $\mathrm{HNO}_{3}$ was $0.7 \sim 6.6$ times higher than observed due to the rapid $\mathrm{HNO}_{3}$ loss in observation on cloudy days. For the Martin Lake plume, the loss rate of $\mathrm{NO}_{\mathrm{y}}$ has been quantified to be $0.148 \mathrm{~h}^{-1}$ in observation, faster than the modeled $\mathrm{NO}_{\mathrm{y}}\left(0.026 \mathrm{~h}^{-1}\right)$ by a factor of 6 since modeled $\mathrm{NO}_{\mathrm{y}}$ loss was insensitive to aqueous processing in the absence of precipitation.

The model effectively simulated the transition between ozone titration and formation but tended to predict lower OPE than indicated by observations. The discrepancies of OPEs between the model and the observations could be explained by the observed rapid $\mathrm{NO}_{\mathrm{y}}$ loss that biases high the observation-based OPE estimates.

\section{Supplement related to this article is available online at: http://www.atmos-chem-phys.net/12/455/2012/ acp-12-455-2012-supplement.pdf.}

Acknowledgements. The work of W. Zhou and D. S. Cohan was funded by the Shell Center for Sustainability at Rice University and National Science Foundation CAREER Award Grant 087386. We thank Robert Griffin at Rice University for helpful discussions on data analyses. We thank Ken Aikin and Harald Stark in the NOAA ESRL Chemical Sciences Division for help in using meteorological and photolysis data. Although this article has been reviewed by the US EPA and approved for publication, it does not necessarily reflect EPA policies or views.

Edited by: C. H. Song

\section{References}

Akimoto, H.: Global Air Quality and Pollution, Science, 302, 1716-1719, doi:10.1126/science.1092666, 2003.

Alexander, B., Park, R. J., Jacob, D. J., and Gong, S.: Transition metal-catalyzed oxidation of atmospheric sulfur: Global implications for the sulfur budget, J. Geophys. Res., 114, D02309, doi:10.1029/2008jd010486, 2009.

Appel, K. W., Roselle, S. J., Gilliam, R. C., and Pleim, J. E.: Sensitivity of the Community Multiscale Air Quality (CMAQ) model v4.7 results for the eastern United States to MM5 and WRF meteorological drivers, Geosci. Model Dev., 3, 169-188, doi:10.5194/gmd-3-169-2010, 2010.

Brock, C. A., Washenfelder, R. A., Trainer, M., Ryerson, T. B., Wilson, J. C., Reeves, J. M., Huey, L. G., Holloway, J. S., Parrish, D. D., Hübler, G., and Fehsenfeld, F. C.: Particle growth in the plumes of coal-fired power plants, J. Geophys. Res.-Atmos., 107, D4155, doi:10.1029/2001jd001062, 2002.

Brock, C. A., Trainer, M., Ryerson, T. B., Neuman, J. A., Parrish, D. D., Holloway, J. S., Nicks, D. K., Jr., Frost, G. J., Hübler, G., Fehsenfeld, F. C., Wilson, J. C., Reeves, J. M., Lafleur, B. G., Hilbert, H., Atlas, E. L., Donnelly, S. G., Schauffler, S. M., Stroud, V. R., and Wiedinmyer, C.: Particle growth in urban and industrial plumes in Texas, J. Geophys. Res.-Atmos., 108, D4111, doi:10.1029/2002jd002746, 2003.
Byun, D. and Schere, K. L.: Review of the Governing Equations, Computational Algorithms, and Other Components of the Models-3 Community Multiscale Air Quality (CMAQ) Modeling System, Appl. Mech. Rev., 59, 27-50, 2006.

Colella, P. and Woodward, P. R.: The Piecewise Parabolic Method (PPM) for gas-dynamical simulations, J. Comput. Phys., 54, 174-201, 1984.

Crutzen, P. J. and Lawrence, M. G.: The Impact of Precipitation Scavenging on the Transport of Trace Gases: A 3Dimensional Model Sensitivity Study, J. Atmos. Chem., 37, 81112, doi:10.1023/a:1006322926426, 2000.

Dudhia, J.: Numerical study of convection observed during the winter monsoon experiment using a mesoscale two-dimensional model, J. Atmos. Sci., 46, 3077-3107, 1989.

EPA: Sparse Matrix Opertional Kernel Emission model version 2.4 User's Mannual, http://www.smoke-model.org/version2.4/html, last access: October 2009, 2006.

EPA, US: $\mathrm{NO}_{\mathrm{x}}$ Budget Trading Program 2003 progress and compliance report, Rep. EPA-430-R-04-010, Clean Air Markets Div., Off. of Air and Radiat., Washington, D. C. , 2004.

EPA, US: Acid Rain Program 2002 progress report, Rep. EPA-430R-03-011, Clean Air Markets Div., Off. of Air and Radiat., Washington, DC, USA, 2005.

Flues, M., Hama, P., Lemes, M. J. L., Dantas, E. S. K., and Fornaro, A.: Evaluation of the rainwater acidity of a rural region due to a coal-fired power plant in Brazil, Atmos. Environ., 36, 23972404, 2002.

Foley, K. M., Roselle, S. J., Appel, K. W., Bhave, P. V., Pleim, J. E., Otte, T. L., Mathur, R., Sarwar, G., Young, J. O., Gilliam, R. C., Nolte, C. G., Kelly, J. T., Gilliland, A. B., and Bash, J. O.: Incremental testing of the Community Multiscale Air Quality (CMAQ) modeling system version 4.7, Geosci. Model Dev., 3, 205-226, 10.5194/gmd-3-205-2010, 2010.

Frost, G. J., McKeen, S. A., Trainer, M., Ryerson, T. B., Neuman, J. A., Roberts, J. M., Swanson, A., Holloway, J. S., Sueper, D. T., Fortin, T., Parrish, D. D., Fehsenfeld, F. C., Flocke, F., Peckham, S. E., Grell, G. A., Kowal, D., Cartwright, J., Auerbach, N., and Habermann, T.: Effects of changing power plant $\mathrm{NO}_{\mathrm{x}}$ emissions on ozone in the eastern United States: Proof of concept, J. Geophys. Res.-Atmos., 111, D12306, doi:10.1029/2005jd006354, 2006.

Godowitch, J. M., Gilliland, A. B., Draxler, R. R., and Rao, S. T.: Modeling assessment of point source NOx emission reductions on ozone air quality in the eastern United States, Atmos. Environ., 42, 87-100, 2008a.

Godowitch, Hogrefe, C., and Rao, S. T.: Diagnostic analyses of a regional air quality model: Changes in modeled processes affecting ozone and chemical-transport indicators from $\mathrm{NO}_{\mathrm{x}}$ point source emission reductions, J. Geophys. Res.-Atmos., 113, D19303, doi:10.1029/2007jd009537, 2008b.

Grell, G. A., Dudhia, J., and Stauffer, D. R.: A description of the Fifth-Generation Penn State/NCAR Mesoscale Model (MM5), NCAR Technical Note NCAR/TN-398+STR, 1994.

Griffin, R. J., Johnson, C. A., Talbot, R. W., Mao, H., Russo, R. S., Zhou, Y., and Sive, B. C.: Quantification of ozone formation metrics at Thompson Farm during the New England Air Quality Study (NEAQS) 2002, J. Geophys. Res.-Atmos., 109, D24302, doi:10.1029/2004jd005344, 2004.

Kain, J. S.: The Kain-Fritsch convective parameterization: An up- 
date, J. Appl. Meteorol, 43, 170-181, 2004.

Karamchandani, P., Koo, A., and Seigneur, C.: Reduced Gas-Phase Kinetic Mechanism for Atmospheric Plume Chemistry, Environ. Sci. Technol, 32, 1709-1720, doi:10.1021/es970707u, 1998.

Kim, S. W., Heckel, A., McKeen, S. A., Frost, G. J., Hsie, E. Y., Trainer, M. K., Richter, A., Burrows, J. P., Peckham, S. E., and Grell, G. A.: Satellite-observed U.S. power plant NOx emission reductions and their impact on air quality, Geophys. Res. Lett., 33, L22812, doi:10.1029/2006g1027749, 2006.

Kleinman, L. I., Daum, P. H., Lee, Y.-N., Nunnermacker, L. J., Springston, S. R., Weinstein-Lloyd, J., and Rudolph, J.: Ozone production efficiency in an urban area, J. Geophys. Res.-Atmos., 107, 4733, doi:10.1029/2002jd002529, 2002.

Kreidenweis, S. M., Zhang, Y., and Taylor, G. R.: The effects of clouds on aerosol and chemical species production and distribution 2. Chemistry model description and sensitivity analysis, J. Geophys. Res., 102, 23867-23882, doi:10.1029/97jd00775, 1997.

Liu, S. C., Trainer, M., Fehsenfeld, F. C., Parrish, D. D., Williams, E. J., Fahey, D. W., Hübler, G., and Murphy, P. C.: Ozone Production in the Rural Troposphere and the Implications for Regional and Global Ozone Distributions, J. Geophys. Res.-Atmos., 92, 4191-4207, doi:10.1029/JD092iD04p04191, 1987.

Mauzerall, D. L., Sultan, B., Kim, N., and Bradford, D. F.: NOx emissions from large point sources: variability in ozone production, resulting health damages and economic costs, Atmos. Environ., 39, 2851-2866, 2005 .

Mlawer, E. J., Taubman, S. J., Brown, P. D., Iacono, M. J., and Clough, S. A.: Radiative transfer for inhomogeneous atmospheres: RRTM, a validated correlated-k model for the longwave, J. Geophys. Res.-Atmos., 102, 16663-16682, 1997.

Neuman, J. A., Parrish, D. D., Ryerson, T. B., Brock, C. A., Wiedinmyer, C., Frost, G. J., Holloway, J. S., and Fehsenfeld, F. C.: Nitric acid loss rates measured in power plant plumes, J. Geophys. Res.-Atmos., 109, D23304, doi:10.1029/2004jd005092, 2004.

Neuman, J. A., Parrish, D. D., Trainer, M., Ryerson, T. B., Holloway, J. S., Nowak, J. B., Swanson, A., Flocke, F., Roberts, J. M., Brown, S. S., Stark, H., Sommariva, R., Stohl, A., Peltier, R., Weber, R., Wollny, A. G., Sueper, D. T., Hubler, G., and Fehsenfeld, F. C.: Reactive nitrogen transport and photochemistry in urban plumes over the North Atlantic Ocean, J. Geophys. Res.-Atmos., 111, D23S54, doi:10.1029/2005jd007010, 2006.

Neuman, J. A., Nowak, J. B., Zheng, W., Flocke, F., Ryerson, T. B., Trainer, M., Holloway, J. S., Parrish, D. D., Frost, G. J., Peischl, J., Atlas, E. L., Bahreini, R., Wollny, A. G., and Fehsenfeld, F. C.: Relationship between photochemical ozone production and NOx oxidation in Houston, Texas, J. Geophys. Res.-Atmos., 114, D23S54, doi:10.1029/2008jd011688, 2009.

Nicks, D. K., Holloway, J. S., Ryerson, T. B., Dissly, R. W., Parrish, D. D., Frost, G. J., Trainer, M., Donnelly, S. G., Schauffler, S., Atlas, E. L., Hubler, G., Sueper, D. T., and Fehsenfeld, F. C.: Fossil-fueled power plants as a source of atmospheric carbon monoxide, J. Environ. Monitor., 5, 35-39, 2003.

Nowak, J. B., Neuman, J. A., Bahreini, R., Brock, C. A., Middlebrook, A. M., Wollny, A. G., Holloway, J. S., Peischl, J., Ryerson, T. B., and Fehsenfeld, F. C.: Airborne observations of ammonia and ammonium nitrate formation over Houston, Texas, J. Geophys. Res., 115, D22304, doi:10.1029/2010jd014195, 2010. Nunnermacker, L. J., Kleinman, L. I., Imre, D., Daum, P. H., Lee,
Y. N., Lee, J. H., Springston, S. R., Newman, L., and Gillani, N.: $\mathrm{NO}_{y}$ lifetimes and $\mathrm{O}_{3}$ production efficiencies in urban and power plant plumes: Analysis of field data, J. Geophys. Res.-Atmos., 105, 9165-9176, doi:10.1029/1999jd900753, 2000.

Oppenheimer, C., Kyle, P., Eisele, F., Crawford, J., Huey, G., Tanner, D., Kim, S., Mauldin, L., Blake, D., Beyersdorf, A., Buhr, M., and Davis, D.: Atmospheric chemistry of an Antarctic volcanic plume, J. Geophys. Res.-Atmos., 115, D04303, doi:10.1029/2009jd011910, 2010.

Otte, T. L. and Pleim, J. E.: The Meteorology-Chemistry Interface Processor (MCIP) for the CMAQ modeling system: updates through MCIPv3.4.1, Geosci. Model Dev., 3, 243-256, doi:10.5194/gmd-3-243-2010, 2010.

Parazols, M., Marinoni, A., Amato, P., Abida, O., Laj, P., and Mailhot, G.: Speciation and role of iron in cloud droplets at the puy de Dôme station, Journal of Atmospheric Chemistry, 54, 267-281, doi:10.1007/s10874-006-9026-x, 2006.

Parrish, D. D., Allen, D. T., Bates, T. S., Estes, M., Fehsenfeld, F. C., Feingold, G., Ferrare, R., Hardesty, R. M., Meagher, J. F., Nielsen-Gammon, J. W., Pierce, R. B., Ryerson, T. B., Seinfeld, J. H., and Williams, E. J.: Overview of the Second Texas Air Quality Study (TexAQS II) and the Gulf of Mexico Atmospheric Composition and Climate Study (GoMACCS), J. Geophys. Res.Atmos., 114, D00F08, doi:10.1029/2009jd011842, 2009.

Peischl, J., Ryerson, T. B., Holloway, J. S., Parrish, D. D., Trainer, M., Frost, G. J., Aikin, K. C., Brown, S. S., Dubé, W. P., Stark, H., and Fehsenfeld, F. C.: A top-down analysis of emissions from selected Texas power plants during TexAQS 2000 and 2006, J. Geophys. Res.-Atmos., 115, D16303, doi:10.1029/2009jd013527, 2010.

Pleim, J. E.: A Combined Local and Nonlocal Closure Model for the Atmospheric Boundary Layer. Part I: Model Description and Testing, J. Appl. Meteorol. Clim, 46, 1383-1395, doi:10.1175/JAM2539.1, 2007.

Raja, S., Ravikrishna, R., Kommalapati, R., and Valsaraj, K.: Monitoring of Fogwater Chemistry in the Gulf Coast Urban Industrial Corridor: Baton Rouge (Louisiana), Environmental Monitoring and Assessment, 110, 99-120, doi:10.1007/s10661-005-6281-2, 2005.

Rodríguez, L. A., Watson, I. M., Edmonds, M., Ryan, G., Hards, V., Oppenheimer, C. M. M., and Bluth, G. J. S.: SO2 loss rates in the plume emitted by Soufrière Hills volcano, Montserrat, J. Volcanol. Geoth. Res., 173, 135-147, 2008.

Ryerson, T. B., Buhr, M. P., Frost, G. J., Goldan, P. D., Holloway, J. S., Hübler, G., Jobson, B. T., Kuster, W. C., McKeen, S. A., Parrish, D. D., Roberts, J. M., Sueper, D. T., Trainer, M., Williams, J., and Fehsenfeld, F. C.: Emissions lifetimes and ozone formation in power plant plumes, J. Geophys. Res.-Atmos., 103, D22569, doi:10.1029/98jd01620, 1998.

Ryerson, T. B., Trainer, M., Holloway, J. S., Parrish, D. D., Huey, L. G., Sueper, D. T., Frost, G. J., Donnelly, S. G., Schauffler, S., Atlas, E. L., Kuster, W. C., Goldan, P. D., Hubler, G., Meagher, J. F., and Fehsenfeld, F. C.: Observations of Ozone Formation in Power Plant Plumes and Implications for Ozone Control Strategies, Science, 292, 719-723, 10.1126/science.1058113, 2001.

Ryerson, T. B., Trainer, M., Angevine, W. M., Brock, C. A., Dissly, R. W., Fehsenfeld, F. C., Frost, G. J., Goldan, P. D., Holloway, J. S., Hübler, G., Jakoubek, R. O., Kuster, W. C., Neuman, J. A., Nicks, D. K., Jr., Parrish, D. D., Roberts, J. M., Sueper, 
D. T., Atlas, E. L., Donnelly, S. G., Flocke, F., Fried, A., Potter, W. T., Schauffler, S., Stroud, V., Weinheimer, A. J., Wert, B. P., Wiedinmyer, C., Alvarez, R. J., Banta, R. M., Darby, L. S., and Senff, C. J.: Effect of petrochemical industrial emissions of reactive alkenes and NOx on tropospheric ozone formation in Houston, Texas, J. Geophys. Res.-Atmos., 108, 4249, doi:10.1029/2002jd003070, 2003.

Sillman, S.: Ozone production efficiency and loss of NOx in power plant plumes: Photochemical model and interpretation of measurements in Tennessee, J. Geophys. Res.-Atmos., 105, 91899202, doi:10.1029/1999jd901014, 2000.

Skamarock, W. C., Klemp, J. B., Dudhia, J., Gill, D., Barker, D. M., Duda, M. G., Huang, X.-Y., Ang, W., and Powers, J. G.: A description of the advanced research WRF version 3. NCAR Technical Note NCAR/TN 475 STR, 2008.

Springston, S. R., Kleinman, L. I., Brechtel, F., Lee, Y.-N., Nunnermacker, L. J., and Wang, J.: Chemical evolution of an isolated power plant plume during the TexAQS 2000 study, Atmos. Environ., 39, 3431-3443, 2005.

Srivastava, R. K., Miller, C. A., Erickson, C., and Jambhekar, R.: Emissions of sulfur trioxide from coal-fired power plants, J. Air Waste Manage. Assoc, 54, 750-762, 2004.

Takegawa, N., Kondo, Y., Koike, M., Ko, M., Kita, K., Blake, D. R., Nishi, N., Hu, W., Liley, J. B., Kawakami, S., Shirai, T., Miyazaki, Y., Ikeda, H., Russel-Smith, J., and Ogawa, T.: Removal of $\mathrm{NO}_{\mathrm{x}}$ and $\mathrm{NO}_{\mathrm{y}}$ in biomass burning plumes in the boundary layer over northern Australia, J. Geophys. Res.-Atmos., 108, 4308, doi:10.1029/2002jd002505, 2003.

Thompson, G., Rasmussen, R. M., and Manning, K.: Explicit Forecasts of Winter Precipitation Using an Improved Bulk Microphysics Scheme. Part I: Description and Sensitivity Analysis, Mon. Weather. Rev., 132, 519-542, doi:10.1175/1520-0493, 2004.

Trainer, M., Parrish, D. D., Buhr, M. P., Norton, R. B., Fehsenfeld, F. C., Anlauf, K. G., Bottenheim, J. W., Tang, Y. Z., Wiebe, H. A., Roberts, J. M., Tanner, R. L., Newman, L., Bowersox, V. C., Meagher, J. F., Olszyna, K. J., Rodgers, M. O., Wang, T., Berresheim, H., Demerjian, K. L., and Roychowdhury, U. K.: Correlation of ozone with NOy in photochemically aged air, J. Geophys. Res.-Atmos., 98, 2917-2925, doi:10.1029/92jd01910, 1993.
Trainer, M., Ridley, B. A., Buhr, M. P., Kok, G., Walega, J., Hübler, G., Parrish, D. D., and Fehsenfeld, F. C.: Regional ozone and urban plumes in the southeastern United States: Birmingham, a case study, J. Geophys. Res.-Atmos., 100, 18823-18834, doi:10.1029/95jd01641, 1995.

Vijayaraghavan, K., Zhang, Y., Seigneur, C., Karamchandani, P., and Snell, H. E.: Export of reactive nitrogen from coalfired power plants in the U.S.: Estimates from a plume-ingrid modeling study, J. Geophys. Res.-Atmos., 114, D04308, doi:10.1029/2008jd010432, 2009.

Walcek, C. J., and Taylor, G. R.: A Theoretical Method for Computing Vertical Distributions of Acidity and Sulfate Production within Cumulus Clouds, J. Atmos. Sci., 43, 339-355, doi:10.1175/1520-0469(1986)043<0339:ATMFCV > 2.0.CO;2, 1986.

Xiu, A., and Pleim, J. E.: Development of a Land Surface Model. Part I: Application in a Mesoscale Meteorological Model, J. Appl. Meteorol, 40, 192-209, doi:10.1175/1520-0450(2001), 2001.

Yarwood, G., Rao, S., Yocke, M., and Whitten, G.: Updates to the Carbon Bond Chemical Mechanism: CB05 Final Report to the US EPA, RT-0400675, 2005.

Yamartino, R. J.: Nonnegative, Conserved Scalar Transport Using Grid-Cell-centered, Spectrally Constrained Blackman Cubics for Applications on a Variable-Thickness Mesh, Monthly Weather Review, 121, 753-763, doi:10.1175/15200493(1993)121<0753:NCSTUG>2.0.CO;2, 1993.

Zaveri, R. A., Berkowitz, C. M., Brechtel, F. J., Gilles, M. K., Hubbe, J. M., Jayne, J. T., Kleinman, L. I., Laskin, A., Madronich, S., Onasch, T. B., Pekour, M. S., Springston, S. R., Thornton, J. A., Tivanski, A. V., and Worsnop, D. R.: Nighttime chemical evolution of aerosol and trace gases in a power plant plume: Implications for secondary organic nitrate and organosulfate aerosol formation, NO3 radical chemistry, and N2O5 heterogeneous hydrolysis, J. Geophys. Res., 115, D12304, doi:10.1029/2009jd013250, 2010. 